Cite this: New J. Chem., 2014 38, 3819 3rd March 2014

Accepted 2nd June 2014

DOI: 10.1039/c4nj00317a

www.rsc.org/njc

\section{Tri- and tetrafluoropropionamides derived from chiral secondary amines - synthesis and the conformational studies $\nmid$}

\author{
Monika Bilska-Markowska, ${ }^{*}$ Magdalena Rapp, Tomasz Siodła, Andrzej Katrusiak, \\ Marcin Hoffmann and Henryk Koroniak
}

\begin{abstract}
A convenient procedure for the preparation of tri- and tetrafluoropropionamides derived from $R-(+) /$ $S-(-)-N$-methyl-1-phenylethylamine and cyclic pyrrolidine derivatives has been described. The $\mathrm{X}$-ray analysis and the theoretical calculations have been used to study conformational analysis of obtained compounds. In contrast to single $\alpha$-fluorine substituted amides, which preferred anti conformation around the $\mathrm{F}-\mathrm{C}-\mathrm{C}=\mathrm{O}$ bond, for tetrafluorinated amides the additional trifluoromethyl group forces the conformation of the $\mathrm{F}-\mathrm{C}-\mathrm{C}=\mathrm{O}$ bond as nearly syn.
\end{abstract}

\section{Introduction}

An amide bond is of key importance for all living organisms as the main chemical bond linking amino acids in peptides and proteins. Peptides play a crucial role in most of the biological processes, such as enzymatic catalysis, immune protection and others. ${ }^{1,2}$ Fluorinated amides are very interesting species in the design of peptide mimetics, as amino acid derivatives and as traditional fluorine modified drugs. ${ }^{3,4}$ It is well known that the introduction of fluorine or fluorine-containing groups into organic molecules can cause considerable changes in the physical, chemical and biological properties. ${ }^{5-7}$ Fluorination can change biological activity, as well as physical properties such as lipophilicity etc. Some examples of new drugs, being trifluoromethylated amido compounds, are efavirenz (anti-HIV) ${ }^{8,9}$ and odanacatib (inhibitor of cathepsin K) ${ }^{10}$ (Fig. 1). Moreover, $\alpha$-hydroxy$\alpha$-trifluoromethylated amides arouse interest due to their structural analogy to some of the antiandrogens used in the treatment of prostate cancer in humans. ${ }^{11}$

The introduction of a gem-difluoromethylene group has been proved to increase the biological activity of many pharmaceuticals containing $\beta$ - and $\gamma$-lactam groups. For example, gem-difluoro- $\gamma$ lactam inhibits $\gamma$-lactamase, an enzyme responsible for bacterial resistance to $\gamma$-lactam antibiotics. ${ }^{12}$ Moreover gem-difluoropropargyl amides are useful as suitable building blocks for the synthesis of fluorinated $\delta$-lactams via cycloisomerization. ${ }^{13}$ Another example for application of the fluorine-containing compounds in synthesis

Faculty of Chemistry, Adam Mickiewicz University in Poznań, Umultowska 89b, 61-614 Poznań, Poland. E-mail: mbilska@amu.edu.pl

$\dagger$ CCDC 989111. For crystallographic data in CIF or other electronic format see DOI: $10.1039 / \mathrm{c} 4$ nj00317a

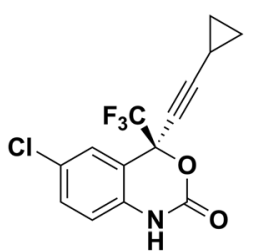

Efavirenz

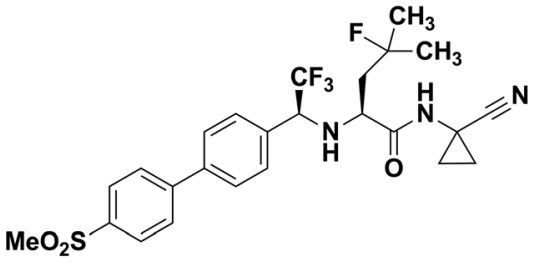

Odanacatib
Fig. 1 Examples of biologically active trifluoromethylated amido compounds.

is trifluoroacetamide analogues that serve as efficient enantioselective nucleophilic trifluoromethylating reagents. ${ }^{14,15}$

Recently, the tri- and tetrafluorinated amides have been studied in our group. ${ }^{16}$ As has been previously reported by Ishikawa, ${ }^{17}$ it has been shown that the hydrolysis of fluorinated enamines or the enamine-amine mixture has given the corresponding fluorinated amides. Additionally, the formation of the $\gamma, \delta$-unsaturated amides, containing the fluorine atom or the $\mathrm{CF}_{3}$ group at the $\alpha$ position to the carbonyl group, via Claisen rearrangement, has been reported. ${ }^{18-20}$

The presence of a fluorine atom in organic molecules can have a significant influence on the preferred conformation. O'Hagan et al. have shown recently that this effect is particularly noticeable in a group of fluorinated carbonyl compounds, especially in amides. ${ }^{21,22}$ When the fluorine atom is placed in the $\alpha$ position to the carbonyl group of an amide it adapts an anti conformation with respect to the $\mathrm{C}=\mathrm{O}$ group and syn with respect to the $\mathrm{C}-\mathrm{N}$ bond. This is a substantial effect of thermodynamic stability estimated to be about 7.5-8.0 kcal mol ${ }^{-1}$ (Scheme 1).

Considering the presence of a fluorine atom in the $\beta$ position with respect to the nitrogen atom of an amide, the fluorine 


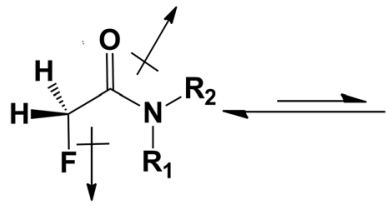

trans $0.0 \mathrm{kcal} \mathrm{mol}^{-1}$

$\mathrm{R}_{1}, \mathrm{R}_{2}=\mathrm{H}$

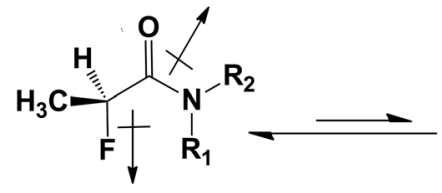

trans $0.0 \mathrm{kcal} \mathrm{mol}^{-1}$

$\mathrm{R}_{1}=\mathrm{H}$

$\mathrm{R}_{2}=\mathrm{CH}_{3}$

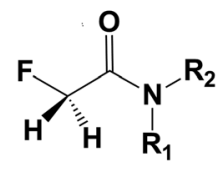

cis $7.5 \mathrm{kcal} \mathrm{mol}^{-1}$

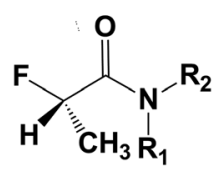

cis $8.0 \mathrm{kcal} \mathrm{mol}^{-1}$
Scheme 1 The energy difference between the trans and cis conformers of $\alpha$-fluoroamides.

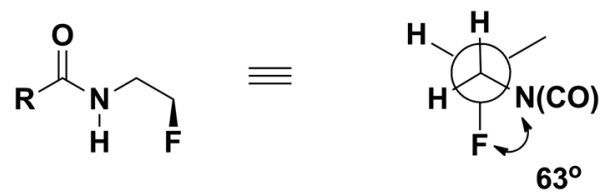

gauche conformation

Fig. 2 Preferred orientation of a fluorine atom in the $\beta$ position with respect to the nitrogen atom of an amide.

atom adopts a conformation in which the $\mathrm{C}-\mathrm{N}$ and $\mathrm{C}-\mathrm{F}$ bonds are oriented gauche to each other, with a dihedral angle of approximately $63^{\circ}$ (Fig. 2)..$^{23}$

In this paper we would like to focus on the synthesis and the conformational analysis of tri- and tetrafluoropropionic acid amides. Addition of hexafluoropropene and 1,1,3,3,3pentafluoropropene to chiral secondary amines, distribution of reaction products, and their usefulness as the new reagents for deoxyfluorination will be published elsewhere.

\section{Results and discussion}

The synthesis of fluorinated amides has been based on the reactions of chiral secondary amines with commercially available 1,1,3,3,3-pentafluoropropene (PFP) or hexafluoropropene (HFP). As the model amines, two enantiomeric $R-(+) / S-(-)-N-$ methyl-1-phenylethylamine $(R / S$-MPEA: series a) and cyclic pyrrolidine derivatives (series b) have been chosen. The first step of synthesis, in the case of reaction of PFP with MPEA, has given the tetrafluorinated enamine 1a (Scheme 2) with a $73 \%$ yield, determined by ${ }^{19} \mathrm{~F}$ NMR.

Changing the solvents to THF or DCM, or increasing temperature (reflux) of this reaction had no influence on the yield. Analysis of ${ }^{19} \mathrm{~F}$ NMR spectra of $1 \mathrm{a}$ confirmed the enamine formation, where one signal of the $\mathrm{CF}_{3}$ group appeared at $\delta:-52.7 \mathrm{ppm}$ (dd) and the second signal from the vinylic fluorine atom at $\delta$ : $-92.7 \mathrm{ppm}(\mathrm{dq})$. The $Z$-configuration of enamine 1a was established on the basis of vinylic fluorine and vicinal hydrogen atom coupling constant values. A characteristic coupling constant for trans arrangement is $J_{\mathrm{F}-\mathrm{H}}^{3}=30.7 \mathrm{~Hz}$, whereas the second (q) coupling constant was equal to $15.2 \mathrm{~Hz}\left(\mathrm{~J}_{\mathrm{F}-\mathrm{CF}_{3}}^{4}\right)$. Usually for $\mathrm{F}$ and $\mathrm{H}$ in trans arrangement coupling constant $J$ varies from $27-32 \mathrm{~Hz}$, while for cis geometry of the double bond $J$ ranges from $4-6 \mathrm{~Hz}^{24-26}$ Exclusive formation of the $Z$-isomer of 1 a could be explained by preferential formation of the most stable zwitterion intermediate, having the $\mathrm{CF}_{3}$ and $\mathrm{NR}_{1}, \mathrm{R}_{2}$ groups in antiperiplanar arrangement, followed by anti fluoride anion elimination (Scheme 3). ${ }^{17,27}$

The high stereoselectivity of enamine formation is of striking difference from the previously reported results of the reaction of PFP with some pyrimidine or purine derivatives. ${ }^{27}$ Thus, the reactions carried out in DMF ( $\mathrm{NaH}$, RT or $60-70{ }^{\circ} \mathrm{C}$ ) yielded a high $Z / E$ ratio of enamines in reaction mixtures. On the other hand, the reactions of PFP with $\mathrm{Et}_{2} \mathrm{NH}$ or $\mathrm{Me}_{2} \mathrm{NH}$ led to $Z$-enamines and only traces of corresponding saturated tertiary fluoroalkylamines. ${ }^{16}$ Analogous reaction of PFP with cyclic amine-pyrrolidine derivatives (series b) has given $Z$-enamines $1 \mathrm{~b}$ as the only product, with a $54 \%$ yield, which was determined by ${ }^{19} \mathrm{~F}$ NMR. The $Z$-geometry of a double bond in enamine $\mathbf{1 b}$ was confirmed by chemical shift analysis of ${ }^{19} \mathrm{~F}$ NMR, i.e. $\delta$ : $-51.7 \mathrm{ppm}\left(\mathrm{CF}_{3}\right.$ group), while a vinylic fluoride signal appeared at $\delta:-87.1 \mathrm{ppm}$ with corresponding coupling constant $J_{\mathrm{F}-\mathrm{H}}^{3}=$ $29.2 \mathrm{~Hz}$ (Table 1). These results are in good agreement with previously reported spectral characteristics of the PFP-pyrrolidine enamine product. ${ }^{16}$

Analogous reaction of appropriate chiral amine (a or $\mathbf{b})$ with HFP has led to a mixture of enamine and fluorinated tertiary amine $2 a-3 a$ with a $79 \%$ yield (the ratio of enamine/amine $2 \mathbf{a} / 3 \mathbf{a}$ was $1: 2$ ), while for $2 \mathbf{b} / 3 \mathbf{b}$ yield was $65 \%$ and the ratio was $1: 32$ (Scheme 3).

The analysis of ${ }^{19} \mathrm{~F}$ NMR spectra of $2 \mathrm{a}$ has indicated the stereochemistry of the enamine double bond, similarly to the reaction with $\mathrm{PFP}$, as $E$-geometry. It has been confirmed by higher values of coupling constants $\left(J_{\mathrm{F}-\mathrm{F}}^{3}=118.7 \mathrm{~Hz}\right.$, trans $)$ between both vicinal fluorine atoms $(\delta:-114.5$ and $\delta:-193.5)$, while signals of the $\mathrm{CF}_{3}$ group have appeared at $\delta:-65.8$ as dd $\left(J_{\mathrm{CF}_{3}-\mathrm{F}}^{4}=13.6 \mathrm{~Hz}, J_{\mathrm{CF}_{3}-\mathrm{F}}^{3}=23.1 \mathrm{~Hz}\right)$. Analogous signals for $2 \mathbf{b}$ have appeared at $\delta$ : -116.8 and -198.8 with $J_{\mathrm{F}-\mathrm{F}}^{3}=116.4 \mathrm{~Hz}$ (indicating $E$-enamine) and $\delta$ : $-65.0\left(\mathrm{CF}_{3}\right)$. Noteworthily, the reaction of secondary amine with HFP has given mainly Michael type addition products - saturated amines $\mathbf{3 a}$ and $\mathbf{3 b}$. The fluorine atom signals of pentafluorinated tertiary amine were located for $3 \mathrm{a}$ at $\delta:-74.5$ to $-74.7\left(\mathrm{CF}_{3}\right)$ and diastereotopic $\left(-\mathrm{CF}_{2}-\right)$ fluorine atoms at $\delta:-81.5$ to -87.5 and $\delta:-87.7$ to -93.3 (multiplets), while for $3 \mathbf{b}$ were situated at $\delta:-74.8$ to $-75.0\left(\mathrm{CF}_{3}\right)$, and at $\delta:-85.6$ to $-86.6(1 \mathrm{~F})$ and at $\delta:-90.4$ to $-91.5(1 \mathrm{~F})$. The high-field shifted fluorine atom signal of $\mathrm{CHFCF}_{3}$ was situated at $\delta:-207.8$ to $-208.3 \mathrm{ppm}$ (multiplet) for $3 \mathrm{a}$, and at $\delta:-205.5$ to -206.0 for $\mathbf{3 b}$ as a multiplet, respectively (Table 1 ).

The formations of major fluoroalkylamines and $E$-enamines, as well as their spectral properties are parallel with analogous 
Series a<smiles>CNC(C)c1ccccc1</smiles><smiles>[X]C(=C(F)F)C(F)(F)F</smiles>

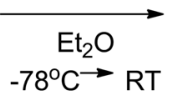

$R / S$ - MPEA

$X=H$ PFP $X=F$ HFP

Series $\mathbf{b}$<smiles>C1=C(C(c2ccccc2)c2ccccc2)NCC1</smiles><smiles>[X]C(=C(F)F)C(F)(F)F</smiles>

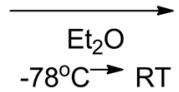

$X=H$ PFP<smiles>[X]C(=C(F)N(C)C(C)c1ccccc1)C(F)(F)F</smiles>

$\mathrm{X}=\mathrm{H} 1 \mathrm{a}$

$\mathrm{X}=\mathrm{F} 2 \mathrm{a}$<smiles></smiles>

$\mathrm{X}=\mathrm{H} \mathbf{1} \mathrm{b}$ $\mathrm{X}=\mathrm{F} \mathbf{2} \mathrm{b}$<smiles>CC(c1ccccc1)N(C)C(F)C(F)(F)F</smiles>

3 a

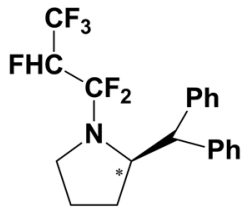

Scheme 2 The synthesis of enamines and mixtures of enamines-amines.

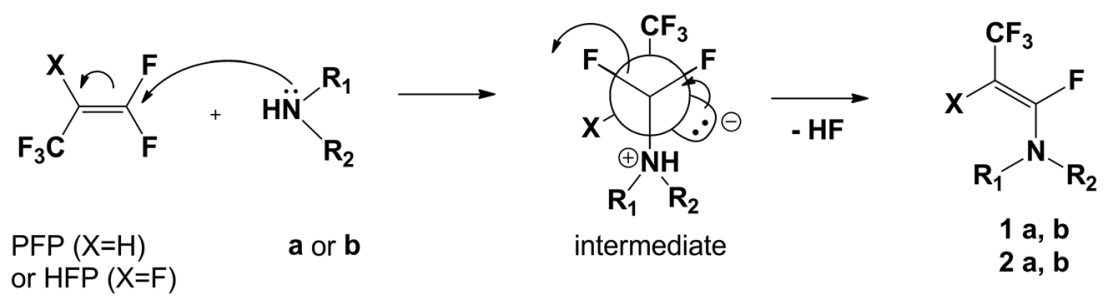

Scheme 3 The formation of the $Z$-isomer of $\mathbf{1} \mathbf{a}, \mathbf{b}(\mathbf{2} \mathbf{a}, \mathbf{b})$.

Table $1{ }^{19} \mathrm{~F}$ NMR chemical shifts (ppm) and coupling constants of enamines $\mathbf{1} \mathbf{a}(\mathbf{1} \mathbf{b}), \mathbf{2} \mathbf{a}(\mathbf{2} \mathbf{b})$ and amines $\mathbf{3 a}(\mathbf{3} \mathbf{b})$

\begin{tabular}{llllll}
\hline Products & & Yield $^{a}[\%]$ & $\mathrm{CF}_{3}$ & $F_{\alpha}{ }^{b}$ & $F_{\beta}{ }^{b}$ \\
\hline Enamines & $\mathbf{1 a}$ & 73 & $-52.7\left(\mathrm{dd}, J^{4}=15.2 \mathrm{~Hz}, J^{3}=7 \mathrm{~Hz}\right)$ & $-92.7\left(\mathrm{dq}, J^{3}=30.7 \mathrm{~Hz}, J^{4}=15.2 \mathrm{~Hz}\right)$ & $\mathrm{n} / \mathrm{a}$ \\
& $\mathbf{1 b}$ & 54 & $-51.7\left(\mathrm{dd}, J^{4}=14.6 \mathrm{~Hz}, J^{3}=7.1 \mathrm{~Hz}\right)$ & $-87.1\left(\mathrm{dq}, J^{3}=29.2 \mathrm{~Hz}, J^{4}=14.6 \mathrm{~Hz}\right)$ & $\mathrm{n} / \mathrm{a}$ \\
& $\mathbf{2 a}$ & 24 & $-65.8\left(\mathrm{dd}, J^{4}=13.6 \mathrm{~Hz}, J^{3}=23.1 \mathrm{~Hz}\right)$ & $-193.5\left(\mathrm{dq}, J^{3}=118.7 \mathrm{~Hz}, J^{4}=13.5 \mathrm{~Hz}\right)$ & $-114.5\left(\mathrm{dq}, J^{3}=118.8 \mathrm{~Hz}\right.$, \\
& 2b & 2 & $-65.0\left(\mathrm{dd}, J^{4}=14.4 \mathrm{~Hz}, J^{3}=22.8 \mathrm{~Hz}\right)$ & $-198.8\left(\mathrm{dq}, J^{3}=118.1 \mathrm{~Hz}, J^{4}=13.4 \mathrm{~Hz}\right)$ & $\left.J^{4}=22.6 \mathrm{~Hz}\right)$ \\
$-116.8\left(\mathrm{dq}, J^{3}=116.4 \mathrm{~Hz}\right.$, \\
\end{tabular}

${ }^{a}$ Yield determined by ${ }^{19} \mathrm{~F}$ NMR using $m$-fluorotoluene as an internal standard $(\delta=-114.1(\mathrm{~m}, 1 \mathrm{~F})) .{ }^{b}$ Positions $\alpha$ and $\beta$ determined in relation to the nitrogen atom.

results reported by Ishikawa et al. ${ }^{17}$ Thus, reaction of diethylamine, $n-\mathrm{Bu}_{2} \mathrm{NH}$ or piperidine with HFP yields an enamine-amine mixture with a different ratio depending on substituent bulkiness. In the case of piperidine as a starting material the only product is amine, while for $\mathrm{Et}_{2} \mathrm{NH}$ as a substrate, the amine/enamine ratio is $1: 3$. On the other hand, the reaction of uracil, cytidine or guanine derivatives with HFP results in mixtures of $E / Z$ isomeric enamines in an almost $1: 1$ ratio, while for adenine analogue the ratio is $2: 1$ - with a major product being $E$-geometry enamine. ${ }^{27}$ Additionally, due to reaction conditions (secondary amine and sodium hydride) fluorinated alkylamine (major product in our case) was not detected in the reaction mixture.

Subsequent $\mathrm{H}_{2} \mathrm{O}$ addition to 1a, 1b enamine double bonds has given 3,3,3-trifluoropropionamide $\mathbf{4 a}, \mathbf{4} \mathbf{b}$, while reactions of water with $\mathbf{2 a}, \mathbf{2 b}$ have given tetrafluorinated analogues $\mathbf{5 a}, \mathbf{5 b}$. Interestingly, contrary to prompt hydrolysis of enamines, in the case of hydrolysis of fluorinated amines $\mathbf{3 a} / \mathbf{3} \mathbf{b}$ addition of Lewis acid such as $\mathrm{BF}_{3}{ }^{*} \mathrm{Et}_{2} \mathrm{O}$ has been necessary (Scheme 4).

Therefore, as a result of water addition to $\mathbf{1 a}$ and $\mathbf{1 b}$, the trifluoropropionamide derivatives $\mathbf{4 a}$ and $\mathbf{4 b}$ were isolated from 
Series a
1 a

2 a $/ 3$ a

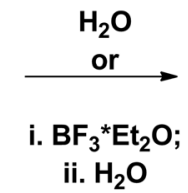

ii. $\mathrm{H}_{2} \mathrm{O}$

Series $b$

$1 \mathrm{~b}$

$2 \mathrm{~b} / 3 \mathrm{~b}$

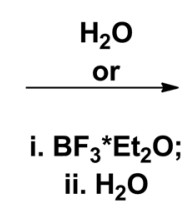

Scheme 4 The hydrolysis reaction of $\mathbf{1 a}, \mathbf{1 b}(\mathbf{2} \mathbf{a}, \mathbf{3} \mathbf{a} / \mathbf{2} \mathbf{b}, \mathbf{3 b})$.

Table $2{ }^{1} \mathrm{H}$ NMR, ${ }^{19} \mathrm{~F}$ NMR chemical shifts (ppm) of trifluoropropionamide derivatives and a reference amide IPMA

\begin{tabular}{|c|c|c|c|c|c|c|c|c|c|c|}
\hline & \multicolumn{5}{|l|}{ Major } & \multicolumn{5}{|l|}{ Minor } \\
\hline & $\mathrm{C} F_{3}$ & $\mathrm{CF}_{3}-\mathrm{CH}_{2}$ & $\mathrm{~N}-\mathrm{R}_{1}{ }^{a}$ & $\mathrm{~N}-\mathrm{R}_{2}{ }^{a}$ & $\mathrm{CH}_{3}{ }^{b}$ & $\mathrm{C} F_{3}$ & $\mathrm{CF}_{3}-\mathrm{CH}_{2}$ & $\mathrm{~N}-\mathrm{R}_{1}{ }^{a}$ & $\mathrm{~N}-\mathrm{R}_{2}{ }^{a}$ & $\mathrm{CH}_{3}{ }^{b}$ \\
\hline IPMA & $\mathrm{n} / \mathrm{a}$ & $\mathrm{n} / \mathrm{a}$ & 2.83 & 4.52 & 1.03 & $\mathrm{n} / \mathrm{a}$ & $\mathrm{n} / \mathrm{a}$ & 2.70 & 3.92 & 1.15 \\
\hline $4 b$ & -62.7 & 2.44 & 3.34 & 4.43 & $\mathrm{n} / \mathrm{a}$ & -63.3 & 2.49 & $3.56 / 3.87$ & 3.17 & $\mathrm{n} / \mathrm{a}$ \\
\hline
\end{tabular}

reaction mixtures with $57 \%$ and $38 \%$ yield, respectively. Analysis of ${ }^{19} \mathrm{~F}$ NMR spectra of $\mathbf{4 a}$ has indicated two triplets at $\delta:-62.9$ and $\delta:-62.8\left(J^{3} \mathrm{CF}_{3}-\mathrm{H}=10.0 \mathrm{~Hz}\right)$ in a $71: 29$ ratio. The phenomenon of the existence of two sets of signals in magnetic resonance spectra is well known in the case of amides. Thus, due to hindered rotation about a partially double amide $\mathrm{C}-\mathrm{N}$ bond, both $N$-substituent groups are chemically non-equivalent and compounds can exist as two rotamers: cisoid and transoid, considering the orientation with respect to the carbonyl group. Alike, in the ${ }^{1} \mathrm{H}$ NMR spectrum of $N, N$-dimethylformamide (DMF) or $N, N$-dimethylacetamide (DMA), both $N$-methyl groups have separate signals. ${ }^{28}$ The observed chemical shift values in the ${ }^{1} \mathrm{H}$ NMR spectrum of methyl groups are $\delta: 2.85 \mathrm{ppm}$ and $\delta: 2.94 \mathrm{ppm}$ for DMF, while for DMA they appear at $\delta: 2.93 \mathrm{ppm}$ and $\delta: 3.03 \mathrm{ppm}$, respectively. In the case of $N, N$-dimethyl-3,3,3trifluoropropionamide, in the ${ }^{1} \mathrm{H}$ NMR spectrum signals from $\mathrm{H}$ atoms of both $N$-neighboring methyl groups are observed at $\delta$ : 3.3 and $\delta: 3.4 \mathrm{ppm}$, while in ${ }^{19} \mathrm{~F}$ NMR spectra the fluorine signal of the $\mathrm{CF}_{3}$ group was located at $\delta:-63.2$ ppm as a triplet. ${ }^{16}$ Similarly, the compound $\mathbf{4 a}$ can exist as two rotamers (Scheme 4): transoid (trans $\mathbf{4 a}$ ) with a larger substituent at nitrogen located in the opposite direction to the carbonyl group and in the reverse direction as rotamer cisoid (cis $\mathbf{4 a}$ ). The analysis of ${ }^{19}$ F NMR spectra has shown two signals: the one of the major rotamer has been located at $\delta$ : -62.9 , while for the minor rotamer of $4 \mathrm{a}$ it has appeared at $\delta:-62.8$ ( $\mathrm{CF}_{3}$ group). Considering the ${ }^{1} \mathrm{H}$ NMR spectra of the $4 \mathbf{a}$ major and minor rotamer, they indicated that the signals of $C$-methyl and $N$-methyl groups for the major rotamer have been located at $\delta$ : 1.42 and $\delta: 2.60$, whereas for the minor rotamer have appeared at $\delta: 1.56$ and $\delta: 2.65$. Also methylene protons of the trifluoropropionic part for the major rotamer have been slightly shifted upfield to $\delta: 3.18$, compared to $\delta: 3.26$ for the minor one. Interestingly, while the chemical shift of aromatic protons for both rotamers was parallel, the difference in the chemical shift of benzylic protons for major and minor rotamers is $\Delta \delta=$ $1.03 \mathrm{ppm}(\delta: 5.99$ for the major and $\delta: 4.95$ for the minor rotamer, respectively) (Table 2 ).

The relationship of the chemical shift values and $N$-neighboring group arrangement in disubstituted amides has already been reported. In the case of $N$-isopropyl- $N$-methyl acetamides (IPMA) the predominant cis geometry $(Z)$ of the i-Pr and the carbonyl $\mathrm{C}=\mathrm{O}$ groups has been determined. ${ }^{29}$ Thus, the cis rotamer signals for $\mathrm{N}$-methyl and $\mathrm{N}-\mathrm{CH}\left(\mathrm{CH}_{3}\right)_{2}$ protons occur at $\delta: 4.52$ and $\delta: 2.83$, whereas for the minor trans rotamer they occur at $\delta$ : 3.92 and $\delta: 2.70$, respectively. The comparison of chemical shift values of benzylic and $N$-methyl protons for both rotamers of $\mathbf{4 a}$, and similarity to IPMA relationships have helped to establish the main rotamer of $\mathbf{4 a}$ as having cis geometry, while the minor rotamer has been determined as having trans geometry. 
Similarly, in ${ }^{13} \mathrm{C}$ NMR spectra of cis and trans isomers of $\mathbf{4 a}$, both sets of signals are typical and analogous for both isomers, with the exceptions of $N$-neighboring atoms like carbons of the $\mathrm{C}-\mathrm{CH}_{3}$ signal at $\delta$ : 15.4 for cis $\mathbf{4 a}$ and at $\delta: 17.9$ for trans $\mathbf{4 a}$, whereas the $N$-methyl group signal for cis $\mathbf{4 a}$ has been located at $\delta$ : 30.1 and for trans $\mathbf{4 a}$ at $\delta: 28.4$. Simultaneously, similarly to ${ }^{1} \mathrm{H}$ NMR spectra, the largest chemical shift difference has been observed in the case of the benzyl carbon atom signals $(C-\mathrm{Ph})$. Thus, the signal for major cis $\mathbf{4 a}$ has been shifted downfield $(\delta: 50.8)$ compared to trans $\mathbf{4 a}(\delta: 55.7)$.

As a result of $\mathbf{1 b}$ hydrolysis, the 3,3,3-trifluoropropionamide $\mathbf{4 b}$, as a mixture of two rotamers with a $53: 47$ ratio, has been isolated. The comparison of the signals in ${ }^{1} \mathrm{H}$ NMR spectra, due to the larger difference in chemical shifts of protons at chiral carbon, has helped matching the major rotamer with $\mathrm{N}-\mathrm{CHC}$ proton shift $\delta: 4.43$ as cis $\mathbf{4 b}$. The minor rotamer with the analogous proton signal situated at $\delta: 3.17$ has been determined as trans $\mathbf{4 b}$. These data are also in agreement with spectral characteristics of pyrrolidine acetamide. ${ }^{30,31}$ While the chemical shifts of the remaining analogous protons in both 4b rotamers have been similar, in ${ }^{19} \mathrm{~F}$ NMR spectra the cis and trans $4 \mathbf{b}$ rotamers of $\mathrm{CF}_{3}$ group signals have appeared at $\delta$ : -62.7 and -63.3 , respectively.

Next, the hydrolysis reactions of enamine-amine mixture $\mathbf{2 a}-\mathbf{3 a}$ and $\mathbf{2} \mathbf{b}-\mathbf{3} \mathbf{b}$ have been performed. The hydrolysis of the 2a-3a mixture has led to formation of $5 \mathbf{a}$ being a mixture of diastereomers $(R, R) /(R, S)$ 5a (in $49: 51$ ratio) with a $78 \%$ isolated yield. Separation of both diastereoisomers has given two fractions (after column chromatography) - crystals and the oil - each consisting of two rotameric forms (77:23 ratio).

Similarly to compounds $\mathbf{4 a}$ and $\mathbf{4 b}$ the comparison of the ${ }^{1} \mathrm{H}$ NMR spectra and the correlation of proton chemical shifts of the $N$-neighboring group in two rotamers with an amide geometry of IPMA and 5a (with a ratio 77:23) have helped to determine the geometry of major rotamers of both diastereomers of $5 \mathbf{a}$ as cis $(Z)$ with the $N$-bulky group oriented in the same direction as the carbonyl group. Thus, the signals of benzylic protons for major rotamers cis $\mathbf{5 a}$ have been down-field shifted and have been located at $\delta: 6.02(R, S)$ and $6.05(R, R)$ while those of $N$-methyl protons have been situated at $\delta: 2.74(R, S)$ and $2.76(R, R)$. The methylbenzyl $\mathrm{C}-\mathrm{CH}_{3}$ protons have been recorded at $\delta$ : $1.55(R, S)$ and $1.54(R, R)$. On the other side, the chemical shift of analogous benzylic ( $\delta$ : 5.24 and 5.30 for both diastereoisomers) and methylic protons ( $\delta: 2.71 / 2.72$ and $1.67 / 1.66$ for $R, S / R, R$ diastereoisomers, respectively) in minor rotamers has indicated the trans geometry of $\mathbf{5 a}$ (Table 3). These data are consistent with ${ }^{1} \mathrm{H}$ NMR and ${ }^{13} \mathrm{C}$ NMR spectra reported already for $N, N$-dimethylfluoroacetamide (DMFA) and $N, N$-dimethyl- $\alpha$ fluoropropionamide (DMFP), as well as for $N, N$-dimethyl-3,3,3trifluoroacetamide. ${ }^{17,32}$

Although, the largest difference between chemical shifts of both diastereomers of $\mathbf{5 a}$ has been observed at stereogenic carbon atoms, these notices have not allowed us to clearly distinguish the configuration at the chiral centre in both diastereomers. While for major rotamers in both diastereoisomers 5a, the chemical shifts of appropriate amine moiety protons had been similar $(\Delta \delta \leq 0.3)$, the signals derived from tetrafluorinated amide parts have slightly varied i.e. $\alpha$-fluorines $(\delta$ : -199.2 and -199.5$)$ with $\alpha$-protons $(\delta: 5.43$ and 5.42) and for the trifluoromethyl group $(\delta:-75.6)$. In contrast, for minor rotamers, the signals of $\alpha$-fluorine atoms have been observed at $\delta$ : -196.1 and -197.6 . The chemical shifts of the rest of the appropriate protons in the whole molecule have been similar.

The comparison of chemical shift values for diastereomeric $\alpha$-methoxy- $\alpha$-(trifluoromethyl)phenyl acetic acid (MPTA) analogues could be applied, as has already been applied, in determining absolute configuration of secondary hydroxyl or amine derivatives. ${ }^{33}$ Thus, for the (R)-MTPA amide derivatives of the $(R)$-1-phenylethylamine e.g. $(R, R)$-MTPAPEA, the $\alpha$-positioned $\mathrm{CF}_{3}$ group has been down-field shifted and has been recorded at $\delta:-70.98$, compared to the analogous signal of the $(R, S)$ diastereoisomer located at $\delta:-71.23$ in ${ }^{19} \mathrm{~F}$ NMR spectra. As a comparison, the signal of the $\alpha$-fluorine atom, vicinal to the $\mathrm{C}=\mathrm{O}$ group in the crystal of anti $\mathbf{5 a}$, has been observed at $\delta$ : -196.1 and has resulted in determination of configuration of the 5a diastereoisomer as $(R, R)$. Analogously, a signal of $\alpha$-fluorine in the ${ }^{19} \mathrm{~F}$ NMR spectrum for anti $\mathbf{5 a}$ has been placed at $\delta$ : $\mathbf{1 9 7 . 6}$, indicating the configuration $(R, S)$ for an oily $\mathbf{5 a}$.

Analogous hydrolysis reaction of the $\mathbf{2 b} \mathbf{b}-\mathbf{3 b}$ mixture has given two diastereoisomers $5 \mathbf{b}$, in a 53:47 ratio with $98 \%$ isolated yield, each isomer with a 77:23 rotamers ratio. The diastereoisomers have been inseparable using column chromatography. As the signals at $\delta: 4.08-4.17 \mathrm{ppm}(\mathrm{m})$ and $\delta: 3.40-3.64 \mathrm{ppm}(\mathrm{m})$ corresponding to $\mathrm{N}-\mathrm{CHC}$ and $\mathrm{N}-\mathrm{CH}_{2}{ }^{-}$, respectively, have been matched by integration to the major rotamer having cis geometry of the $N$-bulky group and the $\mathrm{C}=\mathrm{O}$ bond in one diastereomer $\mathbf{5 b}$, the minor one has had the analogous signals located in the range $\delta: 4.00-4.08 \mathrm{ppm}(\mathrm{m})$ and at $\delta: 3.40-3.64 \mathrm{ppm}(\mathrm{m})$ (in the same range) indicating trans orientation analogous groups in $\mathbf{5 b}$. Unfortunately, for the major diastereoisomer of $\mathbf{5 b}$, the signals of

Table $3{ }^{1} \mathrm{H}$ NMR, ${ }^{19} \mathrm{~F}$ NMR chemical shifts (ppm) of tetrafluoropropionamide derivatives and a reference amide IPMA

\begin{tabular}{|c|c|c|c|c|c|c|c|c|c|c|}
\hline & \multicolumn{5}{|l|}{ Major } & \multicolumn{5}{|l|}{ Minor } \\
\hline & $\mathrm{C} F_{3}$ & $\mathrm{C} F / \mathrm{CH}$ & $\mathrm{N}-\mathrm{R}_{1}{ }^{a}$ & $\mathrm{~N}-\mathrm{R}_{2}{ }^{a}$ & $\mathrm{CH}_{3}{ }^{b}$ & $\mathrm{CF}_{3}$ & $\mathrm{CF} / \mathrm{C} H$ & $\mathrm{~N}-\mathrm{R}_{1}{ }^{a}$ & $\mathrm{~N}-\mathrm{R}_{2}{ }^{a}$ & $\mathrm{CH}_{3}{ }^{b}$ \\
\hline IPMA & $\mathrm{n} / \mathrm{a}$ & $\mathrm{n} / \mathrm{a}$ & 2.83 & 4.52 & 1.03 & $\mathrm{n} / \mathrm{a}$ & $\mathrm{n} / \mathrm{a}$ & 2.70 & 3.92 & 1.15 \\
\hline $5 \mathbf{a}(R, R)$ & -75.6 & $-199.2 / 5.43$ & 2.76 & 6.05 & 1.54 & -75.5 & $-196.1 / 5.52$ & 2.72 & 5.30 & 1.66 \\
\hline $5 \mathbf{a}(R, S)$ & -75.6 & $-199.5 / 5.42$ & 2.74 & 6.02 & 1.55 & -75.5 & $-197.6 / 5.53$ & 2.71 & 5.24 & 1.67 \\
\hline $\mathbf{5 b}(S, S)$ & -75.7 & $-200.7 / 5.11$ & $3.08-3.28$ & $3.74-3.82$ & $\mathrm{n} / \mathrm{a}$ & -76.6 & $-202.7 / 5.05$ & $3.08-3.28$ & $3.74-3.82$ & $\mathrm{n} / \mathrm{a}$ \\
\hline $5 \mathbf{b}(S, R)$ & -75.7 & $-200.6 / 4.92$ & $3.40-3.64$ & $4.08-4.17$ & $\mathrm{n} / \mathrm{a}$ & -76.6 & $-203.7 / 4.93$ & $3.40-3.64$ & $4.00-4.08$ & $\mathrm{n} / \mathrm{a}$ \\
\hline
\end{tabular}

${ }^{a}$ IPMA: $\mathrm{R}_{1}=\mathrm{CH}_{3}, \mathrm{R}_{2}=\mathrm{CH}\left(\mathrm{CH}_{3}\right)_{2} ; \mathbf{5 a}: \mathrm{R}_{1}=\mathrm{CH}_{3}, \mathrm{R}_{2}=\mathrm{CHCH}_{3} \mathrm{Ph} ; \mathbf{5 b}: \mathrm{R}_{1}=\mathrm{CH}_{2} \mathrm{CH}_{2}, \mathrm{R}_{2}=\mathrm{CHCH}(\mathrm{Ph})_{2} \cdot{ }^{b} \mathrm{IPMA}: \mathrm{CH}(\mathrm{CH})_{2} ; \mathbf{5 a}: \mathrm{CHCH} \mathrm{Ph}_{3}$ 
hydrogen atoms at chiral carbon, in the amine part, were situated in the same range ( $\delta: 3.74-3.82 \mathrm{ppm})$ as well as the slightly shifted signal of the $N$-neighboring methylene group ( $\delta: 3.08-3.28 \mathrm{ppm})$.

Additionally, for both major diastereomers cis $\mathbf{5 b}$ the signals derived from tetrafluorinated amide parts have slightly varied i.e. $\alpha$-fluorines $(\delta:-200.7$ and 200.6), $\alpha$-protons $(\delta: 5.11$ and $4.92)$ and the trifluoromethyl group $(\delta:-75.7)$. In contrast, for minor trans rotamers of both diastereomers $\mathbf{5 b}$, the signals of $\alpha$-fluorine atoms have been visible at $\delta:-202.7$ and $-203.7 \mathrm{ppm}$, while the chemical shifts of $\alpha$-protons have been observed at $\delta$ : 5.05 and $\delta: 4.93 \mathrm{ppm}$. The signals of $\mathrm{CF}_{3}$ groups have been situated at $\delta:-76.6 \mathrm{ppm}$. Therefore, aiming to absolute configuration assignment in both diastereomeric $\mathbf{5 b}$ (as a pyrrolidine part has already had $S$-configuration), the correlation of fluorine chemical shift values of $\mathrm{CH} F\left(\mathrm{CF}_{3}\right)$ in minor rotamers of $\mathbf{5 b}$ has been performed. The signal of the $\alpha$-fluorine atom, vicinal to the $\mathrm{C}=\mathrm{O}$ group in trans $\mathbf{5 b}$ has appeared at $\delta$ : $-202.7 \mathrm{ppm}$ and could determine the $\mathbf{5 b}$ diastereomer as $(S, S)$. Analogously, the signal of $\alpha$-fluorine in the ${ }^{19} \mathrm{~F}$ NMR spectrum for trans $\mathbf{5 b}$ has been located at $\delta:-203.7 \mathrm{ppm}$, indicating the configuration $(S, R)$ 5b. This assignment is in agreement with the ones performed for $(R, R) /(R, S)$ 5a and $(S, S) /(S, R) \mathbf{5 a}$, as well as $(R, R)$-MTPAPEA. ${ }^{32}$ However, further studies also involving the crystal structure determination would be necessary to the unambiguous assignment of absolute configuration of chiral atoms in the fluorinated amide part of both diastereomers $\mathbf{5 b}$.

\section{Conformational analysis of tetrafluorinated amide - theoretical calculations}

While the orientation of the amine part toward the carbonyl group is easily detectable based on NMR spectra, the influence of fluorine atoms on steric and electronic effects in molecules and preferable conformation of molecules is the well-known phenomenon. Thus, compound 5a could exist in a few conformations taking into account only fluorine and $\mathrm{CF}_{3}$ group orientation with respect to the carbonyl group (Fig. 3). The cis/trans notation deals with the configuration of partially double amide bond $\mathrm{C}(\mathrm{O})-$ $\mathrm{N}$, while syn/anti notation is related to the $\mathrm{F}-\mathrm{C}-\mathrm{C}=\mathrm{O}$ torsion angle (syn is $0^{\circ}$, anti is $180^{\circ}$ ).

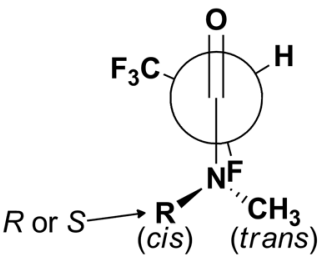

(anti)

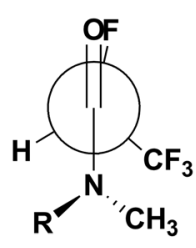

$(s y n)$

$$
\mathrm{R}=-{\underset{\mathrm{Ph}}{\mathrm{C}}}_{\mathrm{H}}^{\mathrm{CH}_{3}}(R \text { or } \mathrm{S})-1 \text {-phenylethyl moiety }
$$

Fig. 3 Anti and syn conformers of $5 \mathbf{a} R, R$ cis (or $R, S$ cis).

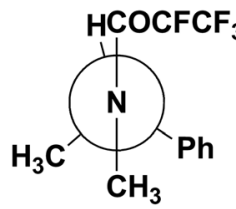

$R$

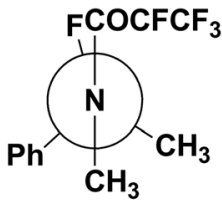

$S$
Fig. 4 Most stable conformational arrangement of the ( $R$ or $S)-1$ phenylethyl moiety, which was used during all optimizations at the DFT level to quantify the dependence of the conformation on the $\mathrm{F}-\mathrm{C}-\mathrm{C}=\mathrm{O}$ torsion angle (Fig. 5).

The most stable conformational arrangement of the ( $R$ or $S$ )1-phenylehtyl moiety has been found (Fig. 4) and used during all optimizations at the DFT level in order to quantify the dependence of the conformation on the $\mathrm{F}-\mathrm{C}-\mathrm{C}=\mathrm{O}$ torsion angle.

The obtained potential energy surfaces (Fig. 5) for 5a: $R, R$ trans, $R, R$ cis, $R, S$ trans and $R, S$ cis are very similar and all show three energy minima (Fig. 6): minimum-1 (deepest minimum at $\mathrm{F}-\mathrm{C}-\mathrm{C}=\mathrm{O}$ torsion angle about $150^{\circ}$ ), minimum-2 (very shallow minimum at about $240^{\circ}$ ) and minimum-3 (at about $330^{\circ}$ ), whose results are in agreement with the data obtained by Abraham et al. for $N, N$-dimethyl- $\alpha$-fluoropropionamide (DMFP) ${ }^{32}$ In contrast to $\alpha$-fluorinated $N$-monosubstituted amides, where the most stable conformation is that with the fluorine atom anti to the carbonyl group, ${ }^{22}$ in the case of $\alpha$-fluorinated $N, N$-disubstituted amides conformation anti is unstable due to the steric congestion (Fig. 5). Two of the three potential energy minima obtained for the 5a are considered to be stable conformers: minimum-1 and minimum -3 (with an $\mathrm{F}-\mathrm{C}-\mathrm{C}=\mathrm{O}$ torsion angle of about $330^{\circ}$ which corresponds to the $\mathrm{X}$-ray structure angle of $331.3^{\circ}$ ) (Fig. 7). There, the X-ray structure is not the global minimum potential energy conformation in the isolated state. Further, the structure of minimum-2 seems to be even a shoulder on the potential energy surface and it is considered to be the least stable minimum due to the relatively high potential energy and a very low energy barrier of rotation (relaxation) towards the global minimum structure (minimum-1). This, on the other hand, is in contrast with the calculation for DMFP, which has a $\mathrm{CH}_{3}$ group instead of a $\mathrm{CF}_{3}$ group. ${ }^{32}$ Then, the structure corresponding to the minimum-2, having the $\mathrm{CH}_{3}$ group in the syn position to the carbonyl $\mathrm{C}=\mathrm{O}$, was the most stable one. In our case, the structure of minimum- 2 has the $\mathrm{CF}_{3}$ group in the syn position to carbonyl which seems to be less preferred due to the repulsion between fluorine and oxygen atoms. This observation shows how additional fluorine atoms can influence the conformation equilibrium.

These data are in agreement with the crystallographic structure of solid 5a (Fig. 7) and $R, R$ absolute configuration determined from ${ }^{19} \mathrm{~F}$ NMR data. The X-ray structure shows that molecule is observed as the syn conformer, with the $\mathrm{O}(1)-\mathrm{C}(1)-$ $\mathrm{N}(1)-\mathrm{C}(4)$ dihedral angle of $355.6^{\circ}$.

Analysis of the X-ray structure of amide $R, R$ syn $\mathbf{5 a}$ shows that the $\mathrm{C}-\mathrm{F}$ bond $\alpha$ to the amide carbonyl group is orientated nearly anti to the $\mathrm{N}-\mathrm{C}$ amide bond, with the $\mathrm{F}(1)-\mathrm{C}(2)-\mathrm{C}(1)-\mathrm{N}(1)$ dihedral angle of $151.9^{\circ}$ and nearly syn to the $\mathrm{C}=\mathrm{O}$ bond, with the $\mathrm{F}(1)-\mathrm{C}(2)-\mathrm{C}(1)-\mathrm{O}(1)$ dihedral angle of $331.3^{\circ}$ (Table 4$)$. 


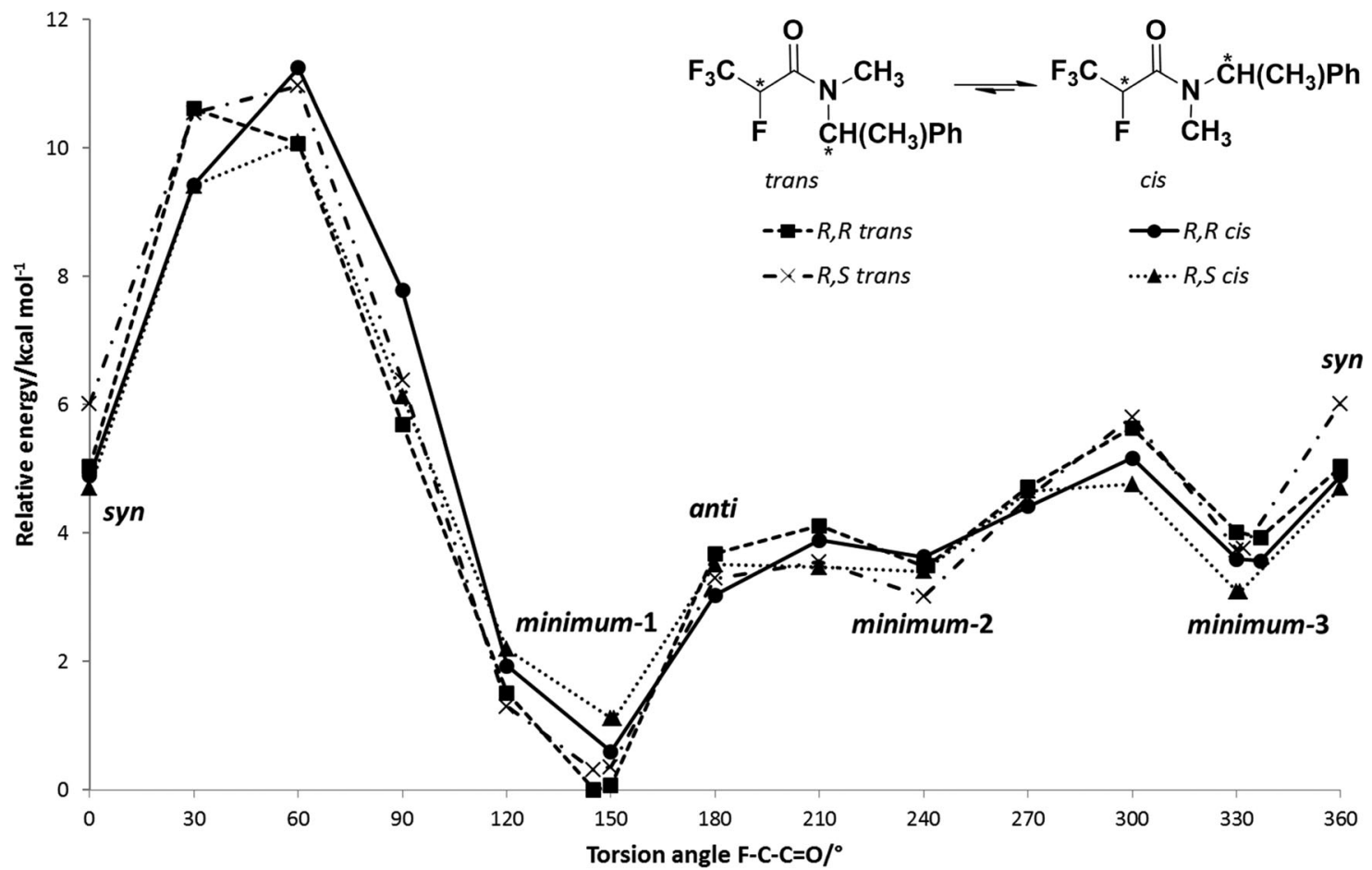

Fig. 5 Potential energy surfaces for 5 a: $R, R$ trans, $R, R$ cis, $R, S$ trans and $R, S$ cis at the wB97XD/cc-pVDZ level.<smiles>[R]N(C)C1(F)CC(=O)CCC(C(F)(F)F)C1</smiles>

(minimum-1)

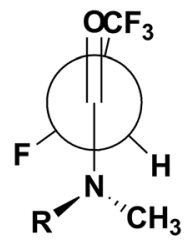

(minimum-2)

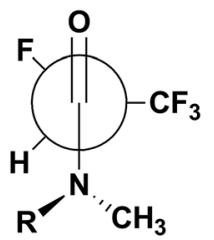

(minimum-3)
Fig. 6 The geometries of three energy minima on the potential energy surface for $\mathbf{5 a} R, R$ cis (or $R, S$ cis).

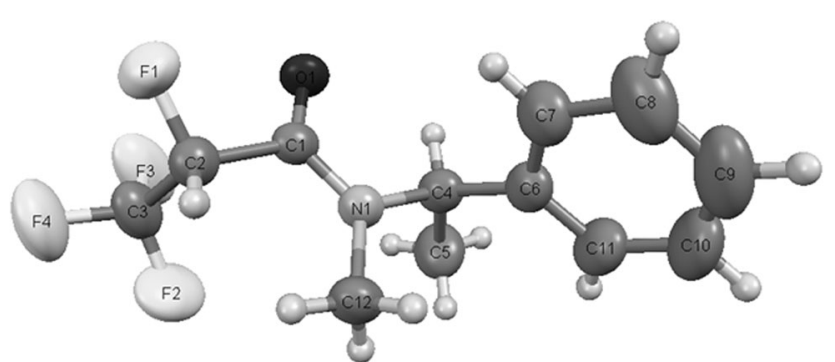

Fig. 7 A perspective drawing and atom labelling of molecule $R, R$ syn $\mathbf{5 a}$ The thermal ellipsoids have been drawn at the $40 \%$ probability level. The hydrogen atoms are shown as small spheres of arbitrary diameter.

It is deviation from the preferred anti conformation of the $\mathrm{F}-\mathrm{C}-\mathrm{C}=\mathrm{O}$ for a single fluorine substituent at the $\alpha$-position with respect to a carbonyl group in $\alpha$-fluoroamides. ${ }^{21,22}$ Following these observations it has been predicted that the preferred conformation around an amide bond could be caused by the
Table 4 Torsion angles $\left(^{\circ}\right)$ of amide $(R, R)$-syn $\mathbf{5 a}$

\begin{tabular}{lr} 
Torsion angles $\left(^{\circ}\right)$ & \\
\hline $\mathrm{C}(3)-\mathrm{C}(2)-\mathrm{C}(1)-\mathrm{O}(1)$ & 88.2 \\
$\mathrm{H}(2) \mathrm{A}-\mathrm{C}(2)-\mathrm{C}(1)-\mathrm{O}(1)$ & 211.2 \\
$\mathrm{~F}(1)-\mathrm{C}(2)-\mathrm{C}(1)-\mathrm{O}(1)$ & 331.3 \\
$\mathrm{~F}(1)-\mathrm{C}(2)-\mathrm{C}(1)-\mathrm{N}(1)$ & 151.9 \\
$\mathrm{C}(3)-\mathrm{C}(2)-\mathrm{C}(1)-\mathrm{N}(1)$ & 268.8 \\
$\mathrm{H}(2) \mathrm{A}-\mathrm{C}(2)-\mathrm{C}(1)-\mathrm{N}(1)$ & 31.8 \\
$\mathrm{O}(1)-\mathrm{C}(1)-\mathrm{N}(1)-\mathrm{C}(12)$ & 176.3 \\
$\mathrm{O}(1)-\mathrm{C}(1)-\mathrm{N}(1)-\mathrm{C}(4)$ & 355.6
\end{tabular}

Table 5 The short intermolecular contacts in the crystal of $\mathbf{5 a}\left(\AA \AA\right.$ and $\left.{ }^{\circ}\right)$

\begin{tabular}{llllll}
$\mathrm{D}-\mathrm{H} \cdots \mathrm{A}$ & $\mathrm{D}-\mathrm{H}$ & $\mathrm{H} \cdots \mathrm{A}$ & $\mathrm{D} \cdots \mathrm{A}$ & $<\mathrm{D}-\mathrm{H} \cdots \mathrm{A}$ & Symmetry code \\
\hline $\mathrm{C} 2-\mathrm{H} 2 \mathrm{a} \cdots \mathrm{O} 1^{a}$ & 0.960 & 2.296 & $3.143(5)$ & 144.17 & $-x, 0.5+y, 1.5-z$ \\
$\mathrm{C} 5-\mathrm{H} 5 \mathrm{a} \cdots \mathrm{F}^{a}$ & 0.960 & 2.624 & $3.470(5)$ & 147.42 & $-x, y-0.5,1.5-z$ \\
$\mathrm{C}^{2}-\mathrm{H} 12 \mathrm{c} \cdots \mathrm{O}^{a}$ & 0.960 & 2.703 & $3.656(5)$ & 171.71 & $1-x, y, z$
\end{tabular}

${ }^{a}$ The $\mathrm{H}$-acceptors transformed according to the symmetry code of the last column.

replacement of the $\mathrm{CH}_{3}$ group by the trifluoromethyl group in the obtained compounds. Not only the fluorine atom but also the trifluoromethyl group dictates the conformation of these amides.

The shortest intermolecular contacts listed in Table 5 show that the strongest interactions can be associated with the proton at $\mathrm{C} 2$ in the most electronegative region of fluorine substituents. These and other shortest interactions bind the molecules along crystallographic plane (001) [Fig. 8]. 


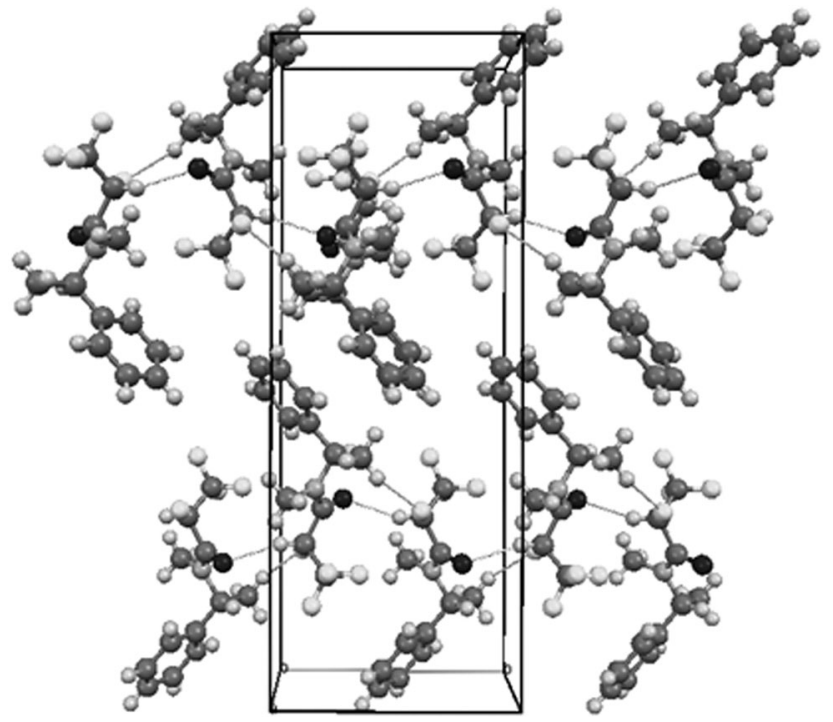

Fig. 8 Autostereographic projection of the crystal structure of $R, R$ syn 5 a viewed down [100], with the shortest contacts indicated as the dashed lines. ${ }^{34}$

\section{IR spectra}

The IR $(\mathrm{C}=\mathrm{O})$ wavenumbers in the series $\mathbf{4 a}-\mathbf{5 a}$ have indicated the influence of the $\mathrm{C}-\mathrm{F}$ bond polarization on the increasing positive charge density on carbon atoms, making the $\mathrm{C}=\mathrm{O}$ bond shorter, due to the electrostatic stability of the $\mathrm{C}-\mathrm{F}$ bond which is consistent with the results from the quantum mechanical calculations. As a reference point, the amide $4 \mathrm{a}$ with a IR $(\mathrm{C}=\mathrm{O}) \nu^{-1} 1659 \mathrm{~cm}^{-1}$ has been selected, while for tetrafluorinated $(R, R) 5 \mathbf{a}$ the wavenumber has equaled to $1655 \mathrm{~cm}^{-1}$. Analogously, for the $(R, S)$ diastereomer $5 \mathbf{a}$ the corresponding $\operatorname{IR}(\mathrm{C}=\mathrm{O}) \nu^{-1}$ has equaled to $1667 \mathrm{~cm}^{-1}$ (Fig. 9).

Probably, in the case of the studied diastereoisomers, the absolute configuration of the carbon atom placed adjacent to the amide bond has an impact on the general polarization, creating the large difference in $\mathrm{C}=\mathrm{O}$ stretching frequency between the diastereoisomers $(R, R)$ and $(R, S)$ of 5a. These data are parallel with the results obtained for (S)-2-fluoro- $N$-(2-fluoroethyl)-propionamide (wavenumber value $\left.1671 \mathrm{~cm}^{-1}\right),{ }^{21}$ indicating an "alfa-fluoroamide effect" and adopting a preferred gauche conformation of the $\mathrm{C}-\mathrm{N}-(\mathrm{C}=\mathrm{O})$ bonds in the $\alpha$-fluoroamide moiety seen in the crystal structure.

\section{Conclusion}

Our experimental results have demonstrated that the hydrolysis reactions of enamines have given 3,3,3-trifluoropropionamides, while an addition of water to enamine-amine mixtures has given tetrafluorinated analogues. The combined spectroscopic, $\mathrm{X}$-ray analyses and theoretical calculations have given us evidence of the differences in the conformational geometry of the $\alpha$-fluorine substituted amides and newly synthesized tri- and tetrafluorinated amide derivatives. According to the latest version of the Cambridge Structural Database, no other structures containing the $\mathrm{C}(\mathrm{F} 3) \mathrm{C}(\mathrm{HF}) \mathrm{C}(=\mathrm{O}) \mathrm{N}-$ have been determined. In contrast to single $\alpha$-fluorine substituted amides which preferred anti conformation of $\mathrm{F}-\mathrm{C}-\mathrm{C}=\mathrm{O}$, for the tetrafluorinated amides the additional trifluoromethyl group has enforced that the $\mathrm{C}-\mathrm{F}$ bond $\alpha$ to the amide carbonyl group is orientated nearly anti to the $\mathrm{N}-\mathrm{C}$ amide bond, and nearly syn to the $\mathrm{C}=\mathrm{O}$ bond. These data could be considered in a design of important $\mathrm{CF}_{3}$-building blocks employed in the synthesis of useful compounds such as peptide analogs.

\section{Experimental section}

\section{General procedures}

${ }^{1} \mathrm{H}\left(\mathrm{Me}_{4} \mathrm{Si}\right)$ NMR spectra were determined with solutions in $\mathrm{CDCl}_{3}$ at $300 \mathrm{MHz},{ }^{13} \mathrm{C}\left(\mathrm{Me}_{4} \mathrm{Si}\right)$ at $75 \mathrm{MHz}$ and ${ }^{19} \mathrm{~F} \mathrm{NMR}\left(\mathrm{CCl}_{3} \mathrm{~F}\right)$ at $282 \mathrm{MHz}$. The yields of reaction products were conveniently evaluated by ${ }^{19} \mathrm{~F} \mathrm{NMR}$ in $\mathrm{CDCl}_{3}$ using $m$-fluorotoluene as an internal standard. Mass spectra were obtained by electron impact (MS-EI) techniques with an ionizing energy of $70 \mathrm{eV}$, unless otherwise noted. Optical rotations were measured at $20{ }^{\circ} \mathrm{C}$ in $\mathrm{CHCl}_{3}$ using a $243 \mathrm{~B}$ Perkin-Elmer polarimeter. $[\alpha]_{\mathrm{D}}$ values were determined at $589 \mathrm{~nm}$. IR spectra were performed using a spectrometer FT-IR IFS 66/s from Bruker. Reagent grade chemicals were used and solvents were dried by refluxing with sodium metal-benzophenone (THF), with $\mathrm{CaH}_{2}$ $\left(\mathrm{CH}_{2} \mathrm{Cl}_{2}\right)$, with $\mathrm{NaH}\left(\mathrm{Et}_{2} \mathrm{O}\right)$ and distilled under an argon atmosphere. All moisture sensitive reactions were carried out under an argon atmosphere using oven-dried glassware. Reaction temperatures below $0{ }^{\circ} \mathrm{C}$ were obtained using a cooling bath (dry ice/isopropanol). Thin-layer chromatography (TLC) was performed on Merck Kieselgel $60-\mathrm{F}_{254}$ with EtOAc-hexane as developing systems. Visualization of the reaction products was achieved using UV light $(254 \mathrm{~nm})$ and a standard procedure (solution of phosphomolybdenic acid or $\mathrm{KMnO}_{4}$ ). Merck Kieselgel 60 (230-400 mesh) was used for column chromatography. 1,1,3,3,3Pentafluoropropene (PFP) and hexafluoropropene (HFP) were provided to us by SynQuest Laboratories Ltd. $R-(+)-$ and $(S)-(-)-N, \alpha-$ dimethylbenzylamine (a) and $\mathrm{BF}_{3}{ }^{*} \mathrm{Et}_{2} \mathrm{O}$ were supplied by Sigma Aldrich. 2(S)-2(Diphenylmethyl)pyrrolidine (b) was achieved according to the known literature method. ${ }^{35-37}$ All products

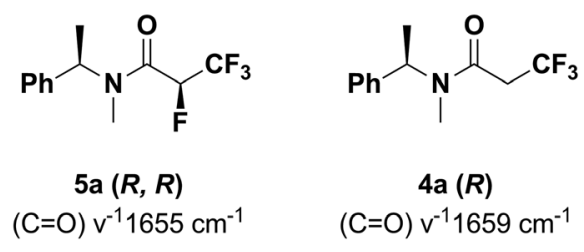<smiles>CC(c1ccccc1)N(C)C(=O)C(F)(F)C(F)(F)F</smiles>

5 a $(R, S)$ $(\mathrm{C}=\mathrm{O}) \mathrm{v}^{-1} 1667 \mathrm{~cm}^{-1}$<smiles>CC(F)C(=O)NCCF</smiles>

(S)-2-fluoro-N-(2-

fluoroethyl)-propionamide $(\mathrm{C}=\mathrm{O}) \mathrm{v}^{-1} 1671 \mathrm{~cm}^{-1}$

Fig. 9 IR $(C=O)$ wavenumbers of series $4 a-5 a$ in comparison with ( $S$ )-2-fluoro- $N$-(2-fluoroethyl)-propionamide. ${ }^{21}$ 
of the analogous reactions provided with $(R)$ or $(S) N$, $\alpha$-dimethylbenzylamine gave the same result with the identical spectral data (with an exception of $[\alpha]$ )-typical for enantiomers.

Theoretical calculations. The quantum mechanical calculations of potential energy in a vacuum with the DFT (wB97XD) method have been performed using the GAUSSIANO3 program, ${ }^{38}$ in order to systematically search for possible conformations. The long-range corrected hybrid functional $\mathrm{wB} 97 \mathrm{XD}^{39}$ with the correlation-consistent polarized basis set cc-pVDZ ${ }^{40}$ has been used as the necessary compromise between the desired accuracy and the computational time needed.

Crystal structure analysis. The structure of compound $R, R$ syn 5a was determined by single-crystal diffraction. A KuMa KM-4 CCD four-circle diffractometer with MoK $\alpha$ radiation $(0.71073 \AA$ ) was used. The structure was solved by direct methods with program SHELXS and refined by full-matrix least squares on $F^{2}$ by SHELXL. ${ }^{41}$ Hydrogen atoms were located from the molecular geometry at idealized positions and assigned isotropic thermal parameters depending on the equivalent displacement parameters of their carriers.

X-ray crystal structure analysis of 5a (CCDC 989111): $\dagger$ formula $\mathrm{C}_{12} \mathrm{H}_{13} \mathrm{~F}_{4} \mathrm{NO}, M=263.23$, colourless crystal $0.30 \times 0.10 \times$ $0.10 \mathrm{~mm}, a=6.07446(13) \AA, b=8.98778(19) \AA, c=24.2410(6) \AA$, $\beta=90^{\circ}, V=1323.46(5) \AA^{3}, \rho_{\text {calc }}=1.321 \mathrm{~g} \mathrm{~cm}^{-3}, \mu=1.075 \mathrm{~mm}^{-1}$, $Z=4$, orthorhombic, space group $P 2_{1} 2_{1} 2_{1}, \lambda=1.54184 \AA$, $T=$ 293(2) K, $\theta$ scans, reflections collected/unique $21223 / 2734$ $[R($ int $)=0.0301], 164$ refined parameters, $R=0.0441, \mathrm{w} R_{2}=$ 0.1384, goodness-of-fit on $F^{2}=1.106$, max. residual electron density 0.257 and -0.164 e $\AA^{-3}$.

\section{General procedure for the synthesis of enamines}

Chiral secondary amine (1 equiv.) and dried solvent ( $3 \mathrm{~mL}$ ) were placed in a glass pressure-vessel. The solution was cooled to $-78{ }^{\circ} \mathrm{C}$ and the pressure was lowered. Next, the excess of 1,1,3,3,3-pentafluoropropene (PFP) was transferred to the glass tube and the vessel was sealed. The cooling bath was removed and the mixture was brought to the room temperature with stirring overnight. After (approximately) 16-24 hours the crude mixture was used for the next step.

Note: The choice of solvent has depended on a solubility of amines. The elevated temperature of reaction (reflux) has not affected the yield.

$(R, Z)-1,3,3,3-T e t r a f l u o r o-N$-methyl- $N$-(1-phenylethyl)prop-1-en1-amine 1a. Reaction of PFP (180 mg, $1.36 \mathrm{mmol})$ and $R-(+)-N, \alpha-$ dimethylbenzylamine $(0.1 \mathrm{~mL}, 92 \mathrm{mg}, 0.68 \mathrm{mmol})$ in dried THF, according to the general procedure, gave a mixture of adduct 1a (yield $73 \%$ ) and traces of amide $\mathbf{4 a}$.

$1 \mathrm{a}^{19} \mathrm{~F}$ NMR $\delta:-52.75\left(3 \mathrm{~F}, \mathrm{dd}, J_{C F_{3}-F}=15.2 \mathrm{~Hz}, J_{C F_{3}-H}=7.0 \mathrm{~Hz}\right.$, $\left.\mathrm{CF}_{3}\right),-92.73\left(1 \mathrm{~F}, \mathrm{dq}, J_{F-H}=30.7 \mathrm{~Hz}, J_{F-C F_{3}}=15.2 \mathrm{~Hz}, \mathrm{~F}\right)$.

(S,Z)-2-Benzhydryl-1-(1,3,3,3-tetrafluoroprop-1-

enyl)pyrrolidine 1b. Reaction of PFP (112 $\mathrm{mg}, 0.85 \mathrm{mmol})$ and 2(S)-2(diphenylmethyl)-pyrrolidine (100 $\mathrm{mg}, 0.42 \mathrm{mmol})$ in dried $\mathrm{CH}_{2} \mathrm{Cl}_{2}$, according to the general procedure led to a mixture of adduct $\mathbf{1 b}$ (yield $54 \%$ ) and traces of amide $\mathbf{4 b}$.

1b ${ }^{19} \mathrm{~F}$ NMR $\delta:-51.68\left(3 \mathrm{~F}, \mathrm{dd}, J_{C_{3}-F}=14.6 \mathrm{~Hz}, J_{C F_{3}-H}=7.1 \mathrm{~Hz}\right.$, $\left.\mathrm{CF}_{3}\right),-87.15\left(1 \mathrm{~F}, \mathrm{dq}, J_{F-H}=29.2 \mathrm{~Hz}, J_{F-C F_{3}}=14.6 \mathrm{~Hz}, \mathrm{~F}\right)$.
General procedure for the synthesis of enamine-amine mixtures

Chiral secondary amine (1 equiv.) and dried solvent ( $3 \mathrm{~mL}$ ) were placed in a glass pressure-vessel. The solution was cooled to $-78{ }^{\circ} \mathrm{C}$ and the pressure was lowered. Next, the excess of hexafluoropropene (HFP) was transferred to the glass tube and the vessel was sealed. The cooling bath was removed and the mixture was brought to the room temperature with stirring overnight. After (approximately) 16-24 hours the crude mixture was used for the next step.

Note: The choice of solvent has depended on a solubility of amines. The elevated temperature of reaction (reflux) has not affected the yield.

$(R, E)-1,2,3,3,3$-Pentafluoro- $N$-methyl- $N$-(1-phenylethyl)prop-1-en1-amine 2a, 1,2,3,3,3-Pentafluoro- $N$-methyl- $N$ - $((R)-1$-phenylethyl)propan-1-amine 3a. Reaction of HFP (180 mg, $1.2 \mathrm{mmol})$ and $R$-(+)- $N, \alpha$-dimethylbenzylamine $(0.1 \mathrm{~mL}, 92 \mathrm{mg}, 0.68 \mathrm{mmol})$, according to the general procedure, gave a mixture of the enamine $2 \mathrm{a}$ (yield 24\%) and amine $3 \mathrm{a}$ (yield 55\%).

2a ${ }^{19} \mathrm{~F}$ NMR $\delta$ : $-65.79\left(3 \mathrm{~F}, \mathrm{dd}, J_{C F_{3}-F}=23.1 \mathrm{~Hz}, J_{C F_{3}-F}=\right.$ $\left.13.6 \mathrm{~Hz}, \mathrm{CF}_{3}\right),-114.48\left(1 \mathrm{~F}, \mathrm{dq}, J_{F-F}=118.8 \mathrm{~Hz}, J_{F-C F_{3}}=22.6 \mathrm{~Hz}, \mathrm{~F}\right)$, $-193.51\left(1 \mathrm{~F}, \mathrm{dq}, J_{F-F}=118.7 \mathrm{~Hz}, J_{F-C F_{3}}=13.5 \mathrm{~Hz}, \mathrm{~F}\right)$.

3a ${ }^{19} \mathrm{~F}$ NMR $\delta$ : -74.50 to $-74.69\left(3 \mathrm{~F}, \mathrm{~m}, \mathrm{CF}_{3}\right),-81.48$ to $-87.53(1 \mathrm{~F}, \mathrm{~m}, \mathrm{~F}),-87.72$ to $-93.33(1 \mathrm{~F}, \mathrm{~m}, \mathrm{~F}),-207.82$ to $-208.26(1 \mathrm{~F}, \mathrm{~m}, \mathrm{~F})$.

(2S,E)-(2-Benzhydryl)-1-(perfluoroprop-1-enyl)pyrrolidine $2 \mathrm{~b}$, (2S)-2-Benzhydryl-1-(1,2,3,3,3-pentafluoropropyl)pyrrolidine $3 \mathrm{~b}$. Reaction of HFP (126 mg, $0.84 \mathrm{mmol}$ ) and 2(S)-2(diphenylmethyl)-pyrrolidine (100 mg, $0.42 \mathrm{mmol}$ ) according to the general procedure gave a mixture of enamine $2 \mathbf{b}$ (yield $2 \%$ ) and amine $\mathbf{3 b}$ (yield 63\%).

2b ${ }^{19} \mathrm{~F}$ NMR $\delta$ : $-65.01\left(3 \mathrm{~F}, \mathrm{dd}, J_{C_{3}-F}=22.8 \mathrm{~Hz}, J_{C F_{3}-F}=\right.$ $\left.14.4 \mathrm{~Hz}, \mathrm{CF}_{3}\right),-116.85\left(1 \mathrm{~F}, \mathrm{dq}, J_{F-F}=116.4 \mathrm{~Hz}, J_{F-C F_{3}}=22.8 \mathrm{~Hz}, \mathrm{~F}\right)$, $-198.85\left(1 \mathrm{~F}, \mathrm{dq}, J_{F-F}=118.1 \mathrm{~Hz}, J_{F-C F_{3}}=13.4 \mathrm{~Hz}, \mathrm{~F}\right)$.

3b ${ }^{19} \mathrm{~F}$ NMR $\delta$ : -74.83 to $-74.96\left(3 \mathrm{~F}, \mathrm{~m}, \mathrm{CF}_{3}\right),-85.57$ to $-86.65(1 \mathrm{~F}, \mathrm{~m}, \mathrm{~F}),-90.42$ to $-91.51(1 \mathrm{~F}, \mathrm{~m}, \mathrm{~F}),-205.53$ to -206.01 (1F, m, F).

\section{General procedure for the synthesis of amide}

Method A. The crude reaction mixture (enamines 1a, b) obtained in the first step was readily hydrolyzed by addition of water ( 2 equiv.). Next, the reaction mixture was dried $\left(\mathrm{Na}_{2} \mathrm{SO}_{4}\right)$, filtered and evaporated under reduced pressure. The product was purified on silica gel (AcOEt-hexane) to give an appropriated amide.

Method B. The crude reaction enamine-amine mixtures $\mathbf{2 a}-\mathbf{3 a}$ and $\mathbf{2} \mathbf{b}-\mathbf{3 b}$ obtained in the first step were readily hydrolyzed by addition of boron trifluoride diethyl etherate (2 equiv.) and water ( 2 equiv.). Next, the reaction mixture was dried $\left(\mathrm{Na}_{2} \mathrm{SO}_{4}\right)$, filtered and evaporated under reduced pressure. The product was purified on silica gel (AcOEt-hexane) to give an appropriated amide.

3,3,3-Trifluoro- $\boldsymbol{N}$-methyl- $\boldsymbol{N}$-((R)-1-phenylethyl)propanamide $4 a$. An enamine 2a was readily hydrolyzed by addition of water (2 equiv.). The product was purified on a silica gel (10\% AcOEt-hexane) to give an amide $4 \mathbf{a}$ (two rotamers with 71/29 ratio), as an oil (96 mg, 57\%). 
$[\alpha]_{\mathrm{D}} 25+172^{\circ}\left(\mathrm{c} 0.4, \mathrm{CHCl}_{3}\right)$.

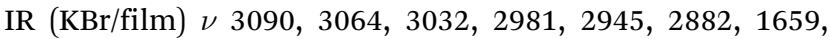
1605, 1586, 1450, 1429, 1406, 1268, 1137, 1114, 1092, 922, 854, $784,701,644$.

Rotamer cis 4a: ${ }^{1} \mathrm{H}$ NMR $\delta: 1.42\left(3 \mathrm{H}, \mathrm{d}, J=7.1 \mathrm{~Hz}, \mathrm{CH}_{3}\right), 2.60$ $\left(3 \mathrm{H}, \mathrm{s}, \mathrm{NCH}_{3}\right), 3.18\left(2 \mathrm{H}, \mathrm{q}, J_{\mathrm{H}_{-C F}}=10.1 \mathrm{~Hz}, \mathrm{CH}_{2}\right), 5.99(1 \mathrm{H}, \mathrm{q}$, $\left.J=7.1 \mathrm{~Hz}, \mathrm{CH}\left(\mathrm{CH}_{3}\right)\right), 7.12-7.33(\mathrm{~m}, 5 \mathrm{H}, \mathrm{Ph}) ;{ }^{13} \mathrm{C}$ NMR $\delta: 15.43$ $\left(\mathrm{CH}_{3}\right), 30.08\left(\mathrm{NCH}_{3}\right), 38.64\left(\mathrm{q}, J=28.9 \mathrm{~Hz}, \mathrm{CH}_{2}\right), 50.80(\mathrm{CH})$, 124.36 (q, $\left.J=276.6 \mathrm{~Hz}, \mathrm{CF}_{3}\right), 127.31(\mathrm{Ph}), 127.63(\mathrm{Ph}), 128.65$ $(\mathrm{Ph}), 139.76(\mathrm{Ph}), 163.41(\mathrm{q}, J=3.1 \mathrm{~Hz}, \mathrm{C}=\mathrm{O}) ;{ }^{19} \mathrm{~F}$ NMR $\delta$ : $-62.90\left(3 \mathrm{~F}, \mathrm{t}, J_{\mathrm{CF}_{3}-\mathrm{H}}=10.0 \mathrm{~Hz}, \mathrm{CF}_{3}\right)$.

Rotamer trans 4a: ${ }^{1} \mathrm{H}$ NMR $\delta: 1.56\left(3 \mathrm{H}, \mathrm{d}, J=6.9 \mathrm{~Hz}, \mathrm{CH}_{3}\right)$, $2.65\left(3 \mathrm{H}, \mathrm{s}, \mathrm{NCH}_{3}\right), 3.26\left(2 \mathrm{H}, \mathrm{q}, J_{H^{-C F_{3}}}=10.0 \mathrm{~Hz}, \mathrm{CH}_{2}\right), 4.95$ $\left(1 \mathrm{H}, \mathrm{q}, J=6.8 \mathrm{~Hz}, \mathrm{CH}\left(\mathrm{CH}_{3}\right)\right), 7.12-7.33(5 \mathrm{H}, \mathrm{m}, \mathrm{Ph}) ;{ }^{13} \mathrm{C} \mathrm{NMR}$ $\delta: 17.89\left(\mathrm{CH}_{3}\right), 28.41\left(\mathrm{NCH}_{3}\right), 38.24\left(\mathrm{q}, J=28.8 \mathrm{~Hz}, \mathrm{CH}_{2}\right), 55.68$ $(\mathrm{CH}), 124.30\left(\mathrm{q}, J=276.7 \mathrm{~Hz}, \mathrm{CF}_{3}\right), 126.33(\mathrm{Ph}), 127.96(\mathrm{Ph})$, $129.01(\mathrm{Ph}), 139.38(\mathrm{Ph}), 163.33(\mathrm{q}, J=2.8 \mathrm{~Hz}, \mathrm{C}=\mathrm{O}) ;{ }^{19} \mathrm{~F}$ NMR $\delta$ : $-62.78\left(3 \mathrm{~F}, \mathrm{t}, J_{\mathrm{CF}_{3}-\mathrm{H}}=10.0 \mathrm{~Hz}, \mathrm{CF}_{3}\right)$.

MS $m / z$ (rel. int.) $245[\mathrm{M}]^{+}(50), 230[\mathrm{M}-15]^{+}(20), 134(5), 120$ (100), 111 (25), 77 (50), 69 (5).

1-((S)-2-Benzhydrylpyrrolidin-1-yl)-3,3,3-trifluoropropan-1-one 4b. An enamine $\mathbf{1 b}$ was readily hydrolyzed by addition of water ( 2 equiv.). The product was purified on a silica gel (20\% AcOEthexane) to give an amide $\mathbf{4 b}$ (two rotamers with 53/47 ratio) as an oil (55 mg, 38\%).

$[\alpha]_{\mathrm{D}} 25^{\circ}+2.3^{\circ}$ (c 2.8, $\left.\mathrm{CHCl}_{3}\right)$.

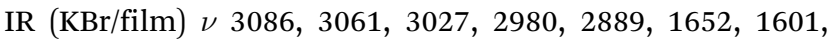
1582, 1494, 1449, 1440, 1350, 1267, 1252, 1218, 1189, 1113, 1032, 919, 851, 754, 701.

Rotamer cis 4b ${ }^{1} \mathrm{H}$ NMR $\delta$ : 1.65-1.80 (1H, m, CHH), 1.87-2.10 $(3 \mathrm{H}, \mathrm{m}, \mathrm{CHH}), 2.44\left(2 \mathrm{H}, \mathrm{q}, J=10.2 \mathrm{~Hz}, \mathrm{CH}_{2} \mathrm{CF}_{3}\right), 3.34(2 \mathrm{H}, \mathrm{dt}$, $J=9.9,8.1 \mathrm{~Hz}, \mathrm{CHHN}), 4.43(1 \mathrm{H}, \mathrm{dt}, J=10.5,5.9 \mathrm{~Hz}, \mathrm{NCH}), 4.63$ $\left(1 \mathrm{H}, \mathrm{d}, J=5.5 \mathrm{~Hz}, \mathrm{CH}(\mathrm{Ph})_{2}\right), 6.97-7.47(\mathrm{~m}, 10 \mathrm{H}, \mathrm{Ph}) ;{ }^{13} \mathrm{C}$ NMR $\delta$ : $23.57\left(\mathrm{CH}_{2}\right), 27.20\left(\mathrm{CH}_{2} \mathrm{CH}\right), 39.80\left(\mathrm{q}, J=28.8 \mathrm{~Hz}, \mathrm{CH}_{2} \mathrm{CF}_{3}\right), 45.04$ $\left(\mathrm{CH}_{2} \mathrm{~N}\right), 51.66\left(\mathrm{CH}(\mathrm{Ph})_{2}\right), 60.25(\mathrm{CH}), 124.16\left(\mathrm{q}, J=276.9 \mathrm{~Hz}, \mathrm{CF}_{3}\right)$, $126.27(\mathrm{Ph}), 127.42(\mathrm{Ph}), 128.06(\mathrm{Ph}), 128.72(\mathrm{Ph}), 128.89(\mathrm{Ph})$, $140.18(\mathrm{Ph}), 141.50(\mathrm{Ph}), 161.84(\mathrm{q}, J=3.3 \mathrm{~Hz}, \mathrm{C}=\mathrm{O}) ;{ }^{19} \mathrm{~F}$ NMR $\delta$ : $-62.74\left(3 \mathrm{~F}, \mathrm{t}, J_{C F_{3}-H}=10.2 \mathrm{~Hz}\right)$.

Rotamer trans $4 \mathbf{b},{ }^{1} \mathrm{H}$ NMR $\delta: 1.65-1.80(1 \mathrm{H}, \mathrm{m}, \mathrm{CH} H), 1.87-$ $2.10(3 \mathrm{H}, \mathrm{m}, \mathrm{CHH}), 2.49\left(2 \mathrm{H}, \mathrm{q}, J=10.3 \mathrm{~Hz}, \mathrm{CH}_{2} \mathrm{CF}_{3}\right), 3.17(1 \mathrm{H}$, $\mathrm{dt}, J=9.9,4.2 \mathrm{~Hz}, \mathrm{NCH}), 3.56(1 \mathrm{H}, \mathrm{dt}, J=12.6,6.6 \mathrm{~Hz}, \mathrm{CH} H \mathrm{~N})$, $3.87(1 \mathrm{H}, \mathrm{dt}, J=12.4,8.1 \mathrm{~Hz}, \mathrm{CHHN}), 4.63(1 \mathrm{H}, \mathrm{d}, J=5.5 \mathrm{~Hz}$, $\left.\mathrm{CH}(\mathrm{Ph})_{2}\right), 6.97-7.47(\mathrm{~m}, 10 \mathrm{H}, \mathrm{Ph}) ;{ }^{13} \mathrm{C}$ NMR $\delta: 21.08\left(\mathrm{CH}_{2}\right), 30.56$ $\left(\mathrm{CH}_{2} \mathrm{CH}\right), 37.63$ (q, $\left.J=28.6 \mathrm{~Hz}, \mathrm{CH}_{2} \mathrm{CF}_{3}\right), 47.58\left(\mathrm{CH}_{2} \mathrm{~N}\right), 53.94$ $\left(C \mathrm{H}(\mathrm{Ph})_{2}\right), 62.99(\mathrm{CH}), 123.98\left(\mathrm{q}, J=276.8 \mathrm{~Hz}, \mathrm{CF}_{3}\right), 126.77(\mathrm{Ph})$, $127.17(\mathrm{Ph}), 128.31(\mathrm{Ph}), 128.84(\mathrm{Ph}), 129.61(\mathrm{Ph}), 141.08(\mathrm{Ph})$, $141.76(\mathrm{Ph}), 162.49(\mathrm{q}, J=3.3 \mathrm{~Hz}, \mathrm{C}=\mathrm{O}) ;{ }^{19} \mathrm{~F}$ NMR $\delta:-63.30$ $\left(3 \mathrm{~F}, \mathrm{t}, J_{C F_{3}-H}=10.3 \mathrm{~Hz}\right)$.

MS $m / z$ (rel. int.) $347[\mathrm{M}]^{+}$(3), 264 (3), 180 (65), 165 (27), 70 (100).

$(S / R)-2,3,3,3-$ Tetrafluoro- $N$-methyl- $N-((R)-1-p h e n y l e t h y l) p r o-$ panamide 5a. The enamine-amine mixture $\mathbf{2 a - 3 a}$ was readily hydrolyzed by addition of water ( 2 equiv.) and boron trifluoride diethyl etherate ( 2 equiv.) giving compound 5a (two diastereoisomers with $51 / 49$ ratio). The product was purified on a silica gel (10\% AcOEt-hexane) to give an amide $(R, S) \mathbf{5 a}$ as an oil
(72 $\mathrm{mg}, 40 \%)$ and an amide $(R, R) \mathbf{5 a}$ as a crystalline solid (68 $\mathrm{mg}, 38 \%$ ), each diastereoisomer as the two rotamers with a $77 / 23$ ratio.

$(\boldsymbol{R}, S) 5 \mathbf{a} .[\alpha]_{\mathrm{D}} 25+118^{\circ}\left(\mathrm{c} 0.2, \mathrm{CHCl}_{3}\right)$.

IR (KBr/film) $\nu$ 3090, 3064, 3032, 2982, 2946, 2883, 1667, 1605,1585 , 1496, 1450, 1420, 1348, 1287, 1266, 1189, 1153, 1128, 1086, 1029, 947, 925, 870, 844, 784, 754, 699, 659.

Rotamer cis $(R, S) 5 \mathbf{a}^{1} \mathrm{H}$ NMR $\delta: 1.55\left(3 \mathrm{H}, \mathrm{d}, J=7.1 \mathrm{~Hz}, \mathrm{CH}_{3}\right)$, $2.74\left(3 \mathrm{H}, \mathrm{d},{ }^{5} J_{\mathrm{CH}_{3}-F}=2.3 \mathrm{~Hz}, \mathrm{NCH}_{3}\right), 5.42\left(1 \mathrm{H}, \mathrm{dq}, J_{H-F}=46.4 \mathrm{~Hz}\right.$, $\left.J_{H-C F_{3}}=6.2 \mathrm{~Hz}, \mathrm{CHF}\right), 6.02\left(1 \mathrm{H}, \mathrm{q}, J=7.0 \mathrm{~Hz}, \mathrm{CH}\left(\mathrm{CH}_{3}\right)\right)$, 7.20-7.44 (m, 5H, Ph), ${ }^{13} \mathrm{C}$ NMR $\delta: 15.13\left(\mathrm{CH}_{3}\right), 29.25\left(\mathrm{NCH}_{3}\right)$, $52.13(\mathrm{CH}), 84.54$ (dq, $J=198.7,34.1 \mathrm{~Hz}, \mathrm{CHF}$ ), 121.30 (dq, $\left.J=282.4, J=26.2 \mathrm{~Hz}, \mathrm{CF}_{3}\right), 127.49(\mathrm{Ph}), 127.99(\mathrm{Ph}), 128.84(\mathrm{Ph})$, $138.95(\mathrm{Ph}), 161.08$ (d, $J=19.4 \mathrm{~Hz}, \mathrm{C}=\mathrm{O}),{ }^{19} \mathrm{~F}$ NMR $\delta:-75.60$ $\left(3 \mathrm{~F}, \mathrm{dd}, J_{C F_{3}-F}=12.9 \mathrm{~Hz}, J_{C F_{3}-H}=6.2 \mathrm{~Hz}, \mathrm{CF}_{3}\right),-199.52(1 \mathrm{~F}, \mathrm{ddq}$, $\left.J_{F-H}=46.4 \mathrm{~Hz}, J_{F-C F_{3}}=12.8 \mathrm{~Hz},{ }^{5} J_{F-C H_{3}}=1.9 \mathrm{~Hz}, \mathrm{~F}\right)$.

Rotamer trans $(R, S) 5 \mathbf{a}^{1} \mathrm{H}$ NMR $\delta: 1.67(3 \mathrm{H}, \mathrm{d}, J=6.8 \mathrm{~Hz}$, $\left.\mathrm{CH}_{3}\right), 2.71\left(3 \mathrm{H}, \mathrm{d},{ }^{5} J_{\mathrm{CH}_{3}-\mathrm{F}}=0.9 \mathrm{~Hz}, \mathrm{NCH}_{3}\right), 5.24(1 \mathrm{H}, \mathrm{q}, J=6.8 \mathrm{~Hz}$, $\left.\mathrm{CH}\left(\mathrm{CH}_{3}\right)\right), 5.53\left(1 \mathrm{H}, \mathrm{dq}, J_{H-F}=46.4 \mathrm{~Hz}, J_{H-C F_{3}}=6.2 \mathrm{~Hz}, \mathrm{CHF}\right)$, 7.20-7.44 (m, 5H, Ph), ${ }^{13} \mathrm{C}$ NMR $\delta: 17.68\left(\mathrm{CH}_{3}\right), 29.84\left(\mathrm{NCH}_{3}\right)$, $54.64(\mathrm{CH}), 85.06$ (dq, $J=199.3,34.0 \mathrm{~Hz}, \mathrm{CHF}), 121.18$ (dq, $\left.J=282.5 \mathrm{~Hz}, J=26.9 \mathrm{~Hz}, \mathrm{CF}_{3}\right), 126.74(\mathrm{Ph}), 128.18(\mathrm{Ph}), 129.05$ $(\mathrm{Ph}), 138.65(\mathrm{Ph}), 160.96(\mathrm{~d}, J=18.8 \mathrm{~Hz}, \mathrm{C}=\mathrm{O}),{ }^{19} \mathrm{~F}$ NMR $\delta$ : $-75.46\left(3 \mathrm{~F}, \mathrm{dd}, J_{\mathrm{CF}_{3}-\mathrm{F}}=13.0 \mathrm{~Hz}, J_{\mathrm{CF}_{3}-\mathrm{H}}=6.2 \mathrm{~Hz}, \mathrm{CF}_{3}\right),-197.58$ $\left(1 \mathrm{~F}, \mathrm{ddq}, J_{F-H}=46.2 \mathrm{~Hz}, J_{F-C F_{3}}=13.0 \mathrm{~Hz},{ }^{5} J_{F-C H_{3}}=0.7 \mathrm{~Hz}, \mathrm{~F}\right)$.

$(\boldsymbol{R}, \boldsymbol{R}) \mathbf{5 a} \cdot[\alpha]_{\mathrm{D}} 25+182^{\circ}\left(\mathrm{c} 0.3, \mathrm{CHCl}_{3}\right)$.

IR (KBr/film) $\nu$ 3088, 3064, 3033, 3000, 2957, 1655, 1606, 1496, 1457, 1425, 1352, 1267, 1189, 1158, 1130, 1089, 1049, 1028, 926, 870, 839, 784, 749, 699, 671, 658.

Rotamer cis $(R, R) 5 \mathrm{a}{ }^{1} \mathrm{H}$ NMR $\delta: 1.54\left(3 \mathrm{H}, \mathrm{d}, J=7.1 \mathrm{~Hz}, \mathrm{CH}_{3}\right)$, $2.76\left(3 \mathrm{H}, \mathrm{d},{ }^{5} J_{\mathrm{CH}_{3}-F}=2.6 \mathrm{~Hz}, \mathrm{NCH}_{3}\right), 5.43\left(1 \mathrm{H}, \mathrm{dq}, J_{H-F}=46.4 \mathrm{~Hz}\right.$, $\left.J_{H-C F_{3}}=6.1 \mathrm{~Hz}, \mathrm{CHF}\right), 6.05\left(1 \mathrm{H}, \mathrm{q}, J=7.1 \mathrm{~Hz}, \mathrm{CH}\left(\mathrm{CH}_{3}\right)\right)$, 7.12-7.56 (m, 5H, Ph), ${ }^{13} \mathrm{C}$ NMR $\delta: 15.18\left(\mathrm{CH}_{3}\right), 29.06\left(\mathrm{NCH}_{3}\right)$, $52.02(\mathrm{CH}), 84.63$ (dq, $J=198.9,34.0 \mathrm{~Hz}, \mathrm{CHF}$ ), 121.30 (dq, $\left.J=282.3, J=26.3 \mathrm{~Hz}, \mathrm{CF}_{3}\right), 127.40(\mathrm{Ph}), 127.92(\mathrm{Ph}), 128.79(\mathrm{Ph})$, $138.95(\mathrm{Ph}), 161.09$ (d, $J=19.1 \mathrm{~Hz}, \mathrm{C}=\mathrm{O}),{ }^{19} \mathrm{~F}$ NMR $\delta:-75.58$ $\left(3 \mathrm{~F}, \mathrm{dd}, J_{C F_{3}-F}=12.8 \mathrm{~Hz}, J_{C F_{3}-H}=6.2 \mathrm{~Hz}, \mathrm{CF}_{3}\right),-199.15(1 \mathrm{~F}, \mathrm{ddq}$, $\left.J_{F-H}=46.7 \mathrm{~Hz}, J_{F-C F_{3}}=12.8 \mathrm{~Hz},{ }^{5} J_{\mathrm{F}_{-C H}}=2.5 \mathrm{~Hz}, \mathrm{~F}\right)$.

Rotamer trans $(R, R) 5 \mathrm{a}^{1} \mathrm{H}$ NMR $\delta: 1.66(3 \mathrm{H}, \mathrm{d}, J=6.8 \mathrm{~Hz}$, $\left.\mathrm{CH}_{3}\right), 2.72\left(3 \mathrm{H}, \mathrm{d},{ }^{5} \mathrm{~J}_{\mathrm{CH}_{3}-\mathrm{F}}=1.0 \mathrm{~Hz}, \mathrm{NCH}_{3}\right), 5.30(1 \mathrm{H}, \mathrm{q}, J=6.8 \mathrm{~Hz}$, $\left.\mathrm{CH}\left(\mathrm{CH}_{3}\right)\right), 5.52\left(1 \mathrm{H}, \mathrm{dq}, J_{H-F}=46.5 \mathrm{~Hz}, J_{H_{-C F}}=6.1 \mathrm{~Hz}, \mathrm{CHF}\right)$, 7.12-7.56 (m, 5H, Ph), ${ }^{13} \mathrm{C}$ NMR $\delta: 17.54\left(\mathrm{CH}_{3}\right), 29.12\left(\mathrm{NCH}_{3}\right)$, $54.48(\mathrm{CH}), 85.89(\mathrm{dq}, J=201.4,34.0 \mathrm{~Hz}, \mathrm{CHF}), 121.18(\mathrm{dq}, J=$ $\left.283.9 \mathrm{~Hz}, J=26.8 \mathrm{~Hz}, \mathrm{CF}_{3}\right), 126.74(\mathrm{Ph}), 128.07(\mathrm{Ph}), 128.95(\mathrm{Ph})$, $138.83(\mathrm{Ph}), 160.98(\mathrm{~d}, J=18.0 \mathrm{~Hz}, \mathrm{C}=\mathrm{O}),{ }^{19} \mathrm{~F}$ NMR $\delta:-75.48$ $\left(3 \mathrm{~F}, \mathrm{dd}, J_{C F_{3}-F}=12.7 \mathrm{~Hz}, J_{C F_{3}-H}=6.4 \mathrm{~Hz}, \mathrm{CF}_{3}\right),-196.08(1 \mathrm{~F}, \mathrm{ddq}$, $\left.J_{F-H}=46.4 \mathrm{~Hz}, J_{F_{-C F}}=12.6 \mathrm{~Hz},{ }^{5} J_{F_{-C H}}=1.0 \mathrm{~Hz}, \mathrm{~F}\right)$.

MS $m / z$ (rel. int.) $263[\mathrm{M}]^{+}(35), 248[\mathrm{M}-15]^{+}$(15), 186 (5), 162 (15), 142 (50), 129 (5), 105 (100), 101 (18), 77 (40), 69 (5).

1-((S)-2-Benzhydrylpyrrolidin-1-yl)-(R/S)-2,3,3,3-tetrafluoropropan-1-one $\mathbf{5 b}$. The enamine-amine mixture $\mathbf{2 b - 3 b}$ were readily hydrolyzed by addition of water ( 2 equiv.) and boron trifluoride diethyl etherate ( 2 equiv.). The crude product was purified on a silica gel (20\% AcOEt-hexane) giving mixture of two diastereoisomers with 53/47 ratio of $5 \mathbf{b}$ as an oil (152 $\mathrm{mg}$, 98\%), each diastereoisomer as a mixture of two rotamers with a 77/23 ratio. 
IR (KBr/film) $\nu$ 3086, 3061, 3028, 2983, 2890, 1667, 1600, 1494, 1450, 1285, 1192, 1142, 869, 701.

Rotamer cis $\mathbf{5 b}$ (major diastereoisomer) ${ }^{1} \mathrm{H}$ NMR $\delta: 1.57-1.70$ $\left(2 \mathrm{H}, \mathrm{m}, \mathrm{CH}_{2}\right), 1.87-2.10\left(2 \mathrm{H}, \mathrm{m}, \mathrm{CH}_{2}\right), 3.08-3.28\left(2 \mathrm{H}, \mathrm{m}, \mathrm{CH}_{2} \mathrm{~N}\right)$, 3.74-3.82 (1H, m, NCH), 4.37 (1H, d, $\left.J=6.9 \mathrm{~Hz}, \mathrm{CH}(\mathrm{Ph})_{2}\right), 5.11$ $\left(1 \mathrm{H}, \mathrm{dq}, J_{H-F}=46.5 \mathrm{~Hz}, J_{H_{-C F}}=6.3 \mathrm{~Hz}, \mathrm{CHF}\right), 6.95-7.45(\mathrm{~m}, 10 \mathrm{H}$, $\mathrm{Ph}),{ }^{13} \mathrm{C}$ NMR $\delta: 25.72\left(\mathrm{CH}_{2}\right), 39.19\left(\mathrm{CH}_{2}\right), 45.66\left(\mathrm{CH}_{2} \mathrm{~N}\right), 51.22$ $\left(\mathrm{CH}(\mathrm{Ph})_{2}\right), 61.10(\mathrm{CH}), 85.57(\mathrm{dq}, J=203.2 \mathrm{~Hz}, J=33.6 \mathrm{~Hz}, \mathrm{CHF})$, $120.52\left(\mathrm{dq}, J=282.1 \mathrm{~Hz}, J=25.5 \mathrm{~Hz}, \mathrm{CF}_{3}\right), 128.41(\mathrm{Ph}), 128.84$ (Ph), $129.56(\mathrm{Ph}), 144.72(\mathrm{Ph}), 159.53(\mathrm{~d}, J=20.5 \mathrm{~Hz}, \mathrm{C}=\mathrm{O}),{ }^{19} \mathrm{~F}$ NMR $\delta:-75.72\left(3 \mathrm{~F}, \mathrm{dd}, J_{C_{3}-F}=13.3 \mathrm{~Hz}, J_{C F_{3}-H}=6.6 \mathrm{~Hz}, \mathrm{CF}_{3}\right)$, $-200.68\left(1 \mathrm{~F}, \mathrm{dq}, J_{F-H}=47.5 \mathrm{~Hz}, J_{F-C F_{3}}=13.4 \mathrm{~Hz}, \mathrm{~F}\right)$.

Rotamer trans $\mathbf{5 b}$ (major diastereoisomer) ${ }^{1} \mathrm{H}$ NMR $\delta: 1.79-$ $1.92\left(2 \mathrm{H}, \mathrm{m}, \mathrm{CH}_{2}\right), 1.87-2.10\left(2 \mathrm{H}, \mathrm{m}, \mathrm{CH}_{2}\right), 3.08-3.28(2 \mathrm{H}, \mathrm{m}$, $\left.\mathrm{CH}_{2} \mathrm{~N}\right), 3.74-3.82(1 \mathrm{H}, \mathrm{m}, \mathrm{NCH}), 4.46(1 \mathrm{H}, \mathrm{d}, J=6.3 \mathrm{~Hz}$, $\left.\mathrm{CH}(\mathrm{Ph})_{2}\right), 5.05\left(1 \mathrm{H}, \mathrm{dq}, J_{H-F}=46.6 \mathrm{~Hz}, J_{H-C F_{3}}=6.6 \mathrm{~Hz}, \mathrm{CHF}\right)$, 6.95-7.45 (m, 10H, Ph), ${ }^{13} \mathrm{C} \mathrm{NMR} \delta: 26.66\left(\mathrm{CH}_{2}\right), 39.34\left(\mathrm{CH}_{2}\right), 46.56$ $\left(\mathrm{CH}_{2} \mathrm{~N}\right), 53.40\left(\mathrm{CH}(\mathrm{Ph})_{2}\right), 61.10(\mathrm{CH}), 85.52(\mathrm{dq}, J=199.7 \mathrm{~Hz}, J=$ $33.5 \mathrm{~Hz}, \mathrm{CHF}$ ), 120.94 (dq, $\left.J=282.8 \mathrm{~Hz}, J=26.3 \mathrm{~Hz}, \mathrm{CF}_{3}\right), 128.45$ (Ph), $129.24(\mathrm{Ph}), 129.30(\mathrm{Ph}), 145.52(\mathrm{Ph}), 161.18$ (d, $J=22.4 \mathrm{~Hz}$, $\mathrm{C}=\mathrm{O}),{ }^{19} \mathrm{~F}$ NMR $\delta$ : $-76.64\left(3 \mathrm{~F}, \mathrm{dd}, J_{\mathrm{CF}_{3}-F}=11.0 \mathrm{~Hz}, J_{\mathrm{CF}_{3}-\mathrm{H}}=6.5 \mathrm{~Hz}\right.$, $\left.\mathrm{CF}_{3}\right),-202.67\left(1 \mathrm{~F}, \mathrm{dq}, J_{F-H}=46.4 \mathrm{~Hz}, J_{F-C F_{3}}=11.1 \mathrm{~Hz}, \mathrm{~F}\right)$.

Rotamer cis $\mathbf{5 b}$ (minor diastereoisomer) ${ }^{1} \mathrm{H}$ NMR $\delta$ : 1.22-1.40 (2H, m, $\left.\mathrm{CH}_{2}\right), 1.79-1.92\left(2 \mathrm{H}, \mathrm{m}, \mathrm{CH}_{2}\right), 3.40-3.64(2 \mathrm{H}$, $\left.\mathrm{m}, \mathrm{CH}_{2} \mathrm{~N}\right), 4.08-4.17(1 \mathrm{H}, \mathrm{m}, \mathrm{NCH}), 4.57(1 \mathrm{H}, \mathrm{d}, J=5.5 \mathrm{~Hz}$, $\left.\mathrm{CH}(\mathrm{Ph})_{2}\right), 4.92\left(1 \mathrm{H}, \mathrm{dq}, J_{H-F}=45.4 \mathrm{~Hz}, J_{H-C F_{3}}=5.5 \mathrm{~Hz}, \mathrm{CHF}\right), 6.95-$ $7.45(\mathrm{~m}, 10 \mathrm{H}, \mathrm{Ph}),{ }^{13} \mathrm{C}$ NMR $\delta: 26.90\left(\mathrm{CH}_{2}\right), 35.06\left(\mathrm{CH}_{2}\right), 46.58$ $\left(\mathrm{CH}_{2} \mathrm{~N}\right), 52.25\left(\mathrm{CH}(\mathrm{Ph})_{2}\right), 61.36(\mathrm{CH}), 85.64(\mathrm{dq}, J=201.2 \mathrm{~Hz}$, $J=33.7 \mathrm{~Hz}, \mathrm{CHF}), 121.03\left(\mathrm{dq}, J=282.2 \mathrm{~Hz}, J=26.0 \mathrm{~Hz}, \mathrm{CF}_{3}\right)$, $128.04(\mathrm{Ph}), 128.63(\mathrm{Ph}), 129.57(\mathrm{Ph}), 140.89(\mathrm{Ph}), 159.49$ (d, $J=$ $19.3 \mathrm{~Hz}, \mathrm{C}=\mathrm{O}),{ }^{19} \mathrm{~F} \mathrm{NMR} \delta:-75.74\left(3 \mathrm{~F}, \mathrm{dd}, J_{\mathrm{CF}_{3}-\mathrm{F}}=12.6 \mathrm{~Hz}, J_{\mathrm{CF}_{3}-\mathrm{H}}=\right.$ $\left.5.9 \mathrm{~Hz}, \mathrm{CF}_{3}\right),-200.59\left(1 \mathrm{~F}, \mathrm{dq}, J_{F-H}=45.7 \mathrm{~Hz}, J_{F-C F_{3}}=12.4 \mathrm{~Hz}, \mathrm{~F}\right)$.

Rotamer trans $\mathbf{5 b}$ (minor diastereoisomer) ${ }^{1} \mathrm{H}$ NMR $\delta: 1.22-$ $1.40\left(2 \mathrm{H}, \mathrm{m}, \mathrm{CH}_{2}\right), 1.41-1.55\left(2 \mathrm{H}, \mathrm{m}, \mathrm{CH}_{2}\right), 3.40-3.64(2 \mathrm{H}, \mathrm{m}$, $\left.\mathrm{CH}_{2} \mathrm{~N}\right), 4.00-4.08(1 \mathrm{H}, \mathrm{m}, \mathrm{NCH}), 4.62\left(1 \mathrm{H}, \mathrm{d}, J=5.5 \mathrm{~Hz}, \mathrm{CH}(\mathrm{Ph})_{2}\right)$, $4.93\left(1 \mathrm{H}, \mathrm{dq}, J_{H-F}=44.4 \mathrm{~Hz}, J_{H_{-C F_{3}}}=6.5 \mathrm{~Hz}, \mathrm{CHF}\right), 6.95-7.45(\mathrm{~m}$, $10 \mathrm{H}, \mathrm{Ph}),{ }^{13} \mathrm{C}$ NMR $\delta: 27.40\left(\mathrm{CH}_{2}\right), 35.26\left(\mathrm{CH}_{2}\right), 46.28\left(\mathrm{CH}_{2} \mathrm{~N}\right)$, $54.25\left(\mathrm{CH}(\mathrm{Ph})_{2}\right), 61.26(\mathrm{CH}), 82.21(\mathrm{dq}, J=209.3 \mathrm{~Hz}, J=33.7 \mathrm{~Hz}$, $\mathrm{CHF}$ ), 120.57 (dq, $\left.J=280.0 \mathrm{~Hz}, J=24.7 \mathrm{~Hz}, \mathrm{CF}_{3}\right), 128.44(\mathrm{Ph})$, $128.93(\mathrm{Ph}), 130.17(\mathrm{Ph}), 140.93(\mathrm{Ph}), 161.20$ (d, $J=21.2 \mathrm{~Hz}$, $\mathrm{C}=\mathrm{O}),{ }^{19} \mathrm{~F}$ NMR $\delta$ : $-76.62\left(3 \mathrm{~F}, \mathrm{dd}, J_{\mathrm{CF}_{3}-\mathrm{F}}=14.4 \mathrm{~Hz}, J_{\mathrm{CF}_{3}-\mathrm{H}}=\right.$ $\left.6.0 \mathrm{~Hz}, \mathrm{CF}_{3}\right),-203.73\left(1 \mathrm{~F}, \mathrm{dq}, J_{F-H}=45.1 \mathrm{~Hz}, J_{F-C F_{3}}=14.4 \mathrm{~Hz}, \mathrm{~F}\right)$.

MS m/z (rel. int.) 264 (5), 198 (100), 165 (20), 129 (3), 101 (5), 77 (2), 70 (50).

\section{References}

1 C. A. G. N. Montalbetti and V. Falque, Tetrahedron, 2005, 61, 10827-10852.

2 E. Valeur and M. Bradley, Chem. Soc. Rev., 2009, 38, 606-631.

3 D. M. Shendage, R. Fröhlisch, K. Bergander and G. Haufe, Eur. J. Org. Chem., 2005, 719-727.

4 A. K. Ghose, V. N. Viswanadhan and J. J. Wendoloski, J. Comb. Chem., 1999, 1, 55-68.
5 P. Kirsch, Modern fluoroorganic chemistry; synthesis, reactivity and application, Wiley-VCH, Weinheim, 2004.

6 K. Uneyama, Organofluorine Chemistry, Blackwell Publishing Ltd., Oxford, 2006.

7 D. O’Hagan, Chem. Soc. Rev., 2008, 37, 308-319.

8 J. Ren, J. Milton, K. L. Weaver, S. A. Short, D. I. Stuart and D. K. Stammers, Structure, 2000, 8, 1089-1094.

9 O. S. Pedersen and E. B. Pedersen, Synthesis, 2000, 479-495. 10 J. Y. Gauthier, N. Chauret, W. Cromlish, S. Desmarais, L. T. Duong, J.-P. Falgueyret, D. B. Kimmel, S. Lamontagne, S. Léger, T. LeRiche, C. S. Li, F. Massé, D. J. McKay, D. A. NicollGriffith, R. M. Oballa, J. T. Palmer, M. D. Percival, D. Riendeau, J. Robichaud, G. A. Rodan, S. B. Rodan, C. Seto, M. Thérien, V.-L. Truong, M. C. Venuti, G. Wesolowski, R. N. Young, R. Zamboni and W. C. Black, Bioorg. Med. Chem. Lett., 2008, 18, 923-928.

11 J. J. Morris, L. R. Hughes, A. T. Glen and P. J. Taylor, J. Med. Chem., 1991, 34, 447-455.

12 R. Joyeau, H. Molines, R. Labia and M. Wakselman, J. Med. Chem., 1988, 31, 370-374.

13 S. Arimitsu and G. B. Hammond, Beilstein J. Org. Chem., 2010, 6, 48.

14 J. Joubert, S. Roussel, C. Christophe, T. Billard, B. R. Langlois and T. Vidal, Angew. Chem., Int. Ed., 2003, 42, 3133-3136.

15 S. Roussel, T. Billard, B. R. Langlois and L. Saint-James, Chem. - Eur. J., 2005, 11, 939-944.

16 H. Koroniak, J. Walkowiak, K. Grys, A. Rajchel, A. Alty and R. Du Boisson, J. Fluorine Chem., 2006, 127, 1245-1251.

17 A. Takaoka, H. Iwakiri and N. Ishikawa, Bull. Chem. Soc. Jpn., 1979, 52(11), 3377-3380.

18 K. Ogu, M. Akazome and K. Ogura, Tetrahedron Lett., 1998, 39, 305-308.

19 K. Ogu, M. Akazome and K. Ogura, J. Fluorine Chem., 2003, 124, 69-80.

20 J. Walkowiak, M. Tomas-Szwaczyk, G. Haufe and H. Koroniak, J. Fluorine Chem., 2012, 143, 189-197.

21 C. R. S. Briggs, D. O'Hagan, J. A. K. Howard and D. S. Yufit, J. Fluorine Chem., 2003, 119, 9-13.

22 J. W. Banks, A. S. Batsanov, J. A. K. Howard, D. O’Hagan, H. S. Rzepa and S. Martin-Santamaria, J. Chem. Soc., Perkin Trans. 2, 1999, 2409-2411.

23 D. O’Hagan, C. Bilton, J. A. K. Howard, L. Knight and D. J. Tozer, J. Chem. Soc., Perkin Trans. 2, 2000, 605-607.

24 P. L. Heinze and D. J. Burton, J. Org. Chem., 1988, 53, 2714-2720. 25 H. Koroniak, K. W. Palmer, W. R. Dolbier Jr and H.-Q. Zhang, Magn. Reson. Chem., 1993, 31, 748-751.

26 W. R. Dolbier Jr, Guide to fluorine NMR for organic chemists, John Wiley \& Sons, Inc., 2009.

27 H. Wójtowicz-Rajchel, H. Koroniak and A. Katrusiak, Eur. J. Org. Chem., 2008, 368-376.

28 R. M. Silverstein, F. X. Webster and D. J. Kiemle, Spectrometric Identification of Organic Compounds, John Wiley \& Sons, Inc., 2005.

29 F. M. Nicolaisen, J. Mol. Struct., 1975, 29, 379-382.

30 D. L. Hooper and R. Kaiser, Can. J. Chem., 1965, 43, 2363-2365. 
31 B. M. Pinto, T. B. Grindley and W. A. Szarek, Magn. Reson. Chem., 1986, 24, 323-331.

32 C. F. Tormena, R. Rittner, R. J. Abraham, E. A. Basso and R. M. Pontes, J. Chem. Soc., Perkin Trans. 2, 2000, 2054-2059.

33 G. R. Sullivan, J. A. Dale and H. S. Mosher, J. Org. Chem., 1973, 38, 2143-2147.

34 A. Katrusiak, J. Mol. Graphics Modell., 2001, 19, 363-367.

35 A. Lattanzi and A. Russo, Tetrahedron, 2006, 62, 12264-12269.

36 M. D. Price, J. K. Sui, M. J. Kurth and N. E. Schore, J. Org. Chem., 2002, 67, 8086-8089.

37 J. Bailey, D. O'Hagan and M. Tavasli, Tetrahedron: Asymmetry, 1997, 8(1), 149-153.

38 M. J. Frisch, G. W. Trucks, H. B. Schlegel, G. E. Scuseria, M. A. Robb, J. R. Cheeseman, J. A. Montgomery Jr., T. Vreven, K. N. Kudin, J. C. Burant, J. M. Millam, S. S. Iyengar, J. Tomasi, V. Barone, B. Mennucci, M. Cossi, G. Scalmani, N. Rega, G. A. Petersson, H. Nakatsuji, M. Hada, M. Ehara, K. Toyota, R. Fukuda, J. Hasegawa, M. Ishida, T. Nakajima, Y. Honda,
O. Kitao, H. Nakai, M. Klene, X. Li, J. E. Knox, H. P. Hratchian, J. B. Cross, V. Bakken, C. Adamo, J. Jaramillo, R. Gomperts, R. E. Stratmann, O. Yazyev, A. J. Austin, R. Cammi, C. Pomelli, J. W. Ochterski, P. Y. Ayala, K. Morokuma, G. A. Voth, P. Salvador, J. J. Dannenberg, V. G. Zakrzewski, S. Dapprich, A. D. Daniels, M. C. Strain, O. Farkas, D. K. Malick, A. D. Rabuck, K. Raghavachari, J. B. Foresman, J. V. Ortiz, Q. Cui, A. G. Baboul, S. Clifford, J. Cioslowski, B. B. Stefanov, G. Liu, A. Liashenko, P. Piskorz, I. Komaromi, R. L. Martin, D. J. Fox, T. Keith, M. A. Al-Laham, C. Y. Peng, A. Nanayakkara, M. Challacombe, P. M. W. Gill, B. Johnson, W. Chen, M. W. Wong, C. Gonzalez and J. A. Pople, Gaussian 03, Revision C.02, Gaussian, Inc., Wallingford, CT, 2004.

39 J. D. Chai and M. Head-Gordon, Phys. Chem. Chem. Phys., 2008, 10, 6615-6620.

40 T. H. Dunning Jr., J. Chem. Phys., 1989, 90, 1007-1023.

41 G. M. Sheldrick, Acta Crystallogr., Sect. A: Found. Crystallogr., 2008, 64, 112-122. 